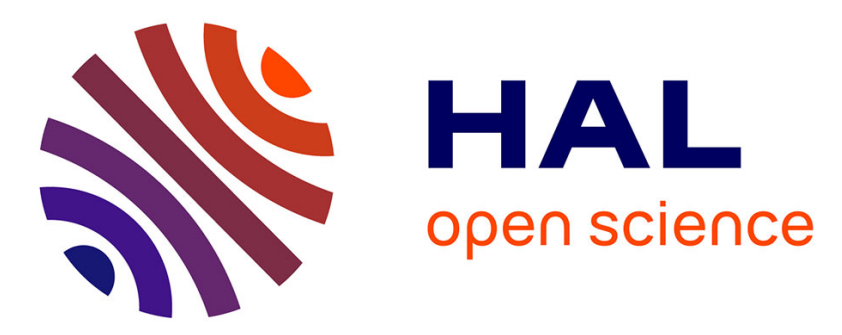

\title{
Miocene Subsidence and Surface Uplift of Southernmost Tibet Induced by Indian Subduction Dynamics
}

\author{
T. Shen, Gang Wang, A. Replumaz, L. Husson, A. Webb, M. Bernet, P. \\ Leloup, P. Zhang, G. Mahéo, K. Zhang
}

\section{- To cite this version:}

T. Shen, Gang Wang, A. Replumaz, L. Husson, A. Webb, et al.. Miocene Subsidence and Surface Uplift of Southernmost Tibet Induced by Indian Subduction Dynamics. Geochemistry, Geophysics, Geosystems, 2020, 21 (10), 10.1029/2020GC009078 . hal-02999040

\section{HAL Id: hal-02999040 \\ https://hal.science/hal-02999040}

Submitted on 7 Jan 2022

HAL is a multi-disciplinary open access archive for the deposit and dissemination of scientific research documents, whether they are published or not. The documents may come from teaching and research institutions in France or abroad, or from public or private research centers.
L'archive ouverte pluridisciplinaire $\mathbf{H A L}$, est destinée au dépôt et à la diffusion de documents scientifiques de niveau recherche, publiés ou non, émanant des établissements d'enseignement et de recherche français ou étrangers, des laboratoires publics ou privés.

$$
\text { Copyright }
$$




\section{Geochemistry, Geophysics, Geosystems}

\author{
RESEARCH ARTICLE \\ 10.1029/2020GC009078 \\ Key Points: \\ - Gangdese batholith experienced \\ reheating between $\sim 28$ and $20 \mathrm{Ma}$, \\ followed by rapid cooling between \\ 20-17 Ma at a rate of $\sim 50{ }^{\circ} \mathrm{C} / \mathrm{Myr}$ \\ - The northward migration of the \\ Indian continent created a wave of \\ dynamic topography that caused the \\ successive subsidence and uplift \\ - The Kailas basin is a unique \\ occurrence of a perched basin that \\ owes its existence to dynamic \\ deflection within a mountain belt \\ Supporting Information: \\ - Supporting Information S1 \\ - Supporting Information S2 \\ - Text S1 \\ - Table S1
}

Correspondence to:

T. Shen,

shenty@cug.edu.cn

Citation:

Shen, T., Wang, G., Replumaz, A., Husson, L., Webb, A. A. G., Bernet, M., et al. (2020). Miocene subsidence and surface uplift of southernmost Tibet induced by Indian subduction dynamics. Geochemistry, Geophysics, Geosystems, 21, e2020GC009078.

https://doi.org/10.1029/2020GC009078

Received 6 APR 2020

Accepted 10 SEP 2020

Accepted article online 22 SEP 2020

(C)2020. American Geophysical Union. All Rights Reserved.

\section{Miocene Subsidence and Surface Uplift of Southernmost Tibet Induced by Indian Subduction Dynamics}

\author{
T. Shen ${ }^{1}$ (D) G. Wang' (D, A. Replumaz ${ }^{2}$ iD, L. Husson' ${ }^{2}$ iD, A. A. G. Webb ${ }^{3}$ iD, M. Bernet ${ }^{2}$, \\ P. H. Leloup ${ }^{4}$ iD, P. Zhang', G. Mahéo ${ }^{4}$, and K. Zhang ${ }^{5}$ \\ ${ }^{1}$ School of Earth Sciences, Center for Global Tectonics, and State Key Laboratory of Geological Processes and Mineral \\ Resources, China University of Geosciences, Wuhan, China, ${ }^{2}$ Institut des Sciences de la Terre, Université Grenoble Alpes, \\ CNRS, Grenoble, France, ${ }^{3}$ Division of Earth and Planetary Science and Laboratory for Space Research, University of Hong \\ Kong, Hong Kong, ${ }^{4}$ Laboratoire de Géologie de Lyon, CNRS UMR 5570, Université de Lyon 1, Villeurbanne, France, \\ ${ }^{5}$ School of Earth Sciences and State Key Laboratory of Biogeology and Environmental Geology, China University of \\ Geosciences, Wuhan, China
}

Abstract The Indus-Yarlung suture of southernmost Tibet marks the initial collisional zone, the ongoing India-Asia collision, and yet more than $~ 30$ million years after the onset of collision, a thick detrital sedimentary unit was deposited just north of the suture: the Kailas Formation. The mechanism permitting subsidence of the deep intracontinental Kailas basin in a compressional tectonic regime remains uncertain. We present new apatite (16-11 Ma) and zircon (24-19 Ma) fission track (AFT and ZFT) ages from the Gangdese batholith just north of the Kailas basin. ZFT analysis of modern-river sand from the northern Gangdese magmatic arc indicates an exhumation at 27.3 $\pm 1.3 \mathrm{Ma}$. Thermal modeling indicates that the batholith experienced reheating between 28 and $20 \mathrm{Ma}$, coeval with deposition in the Kailas basin (between 26 and $21 \mathrm{Ma}$ ), followed by overall rapid cooling between 20 and $17 \mathrm{Ma}$. We interpret this thermal history as a phase of regional Oligocene-Miocene sedimentary burial followed by exhumation. By modeling mantle dynamics in the geodynamic framework of the India-Asia collision, we show that transient dynamic topography over the relative southward folding of the Indian slab is consistent with burial and exhumation of the Gangdese magmatic arc during Oligocene-Miocene time. The northward migration of the Indian continent relative to its own stati onary slab created a wave of dynamic topography that caused subsidence in the overriding plate north of the Himalaya, followed by a phase of surface uplift since 27 Ma of the northern Gangdese magmatic arc. During latest Oligocene-early Miocene time, the dynamic deflection center was in the Kailas area, and it progressively relocated southward to its present position at the Ganges basin.

\section{Introduction}

The continent-continent collision between the Indian and Eurasian plates, following the northward movement of the Indian plate since the early Cenozoic, formed the Tibetan Plateau (DeCelles et al., 2014; Dewey, 1988; Hu et al., 2016; Najman et al., 2010). The orogenic deformation front has migrated both northward and southward from the initial collision zone at the Yarlung-Tsangpo suture zone (Kapp \& DeCelles, 2019; Replumaz \& Tapponnier, 2003; Tapponnier et al., 2001; Yin, 2010). In the center of this large Cenozoic continental collision zone, thick conglomerate layers were deposited during the Oligocene to Miocene and are exposed along strike to the north of the Indus-Yarlung suture zone with an east-west extension of more than 1,000 km but with a north-south width of less than $10 \mathrm{~km}$ (Heim \& Gansser, 1939; Yin et al., 1999). These rocks have been referred to as the Kailas Formation, named after the most famous holy mountain in Tibet, Mt. Kailas (Cheng \& Xu, 1986), which is located in western Tibet and is composed of subhorizontal conglomerates (e.g., DeCelles et al., 2011; Lacassin et al., 2004). The sediments of the current 6,566-m-high peak have been buried to a depth of $~ 4-7 \mathrm{~km}$ during the early Miocene and have experienced significant exhumation at $17 \mathrm{Ma}$ (Carrapa et al., 2014). In other places, the Kailas Formation experienced variable rates of accumulation, burial, exhumation, and deformation (Leary et al., 2016; Sanchez et al., 2013; Yin et al., 1999). Therefore, it could provide critical information for understanding the processes of India-Asian continental collision during the Cenozoic. However, the tectonic context of the conglomerates is still debated, with points of view including a foreland basin related to the southward thrusting Gangdese Thrust (GT) (Yin et al., 1999), a flexural basin associated with the termination or renewal of India-Asia 
collision (Aitchison et al., 2007; Wang et al., 2015), and an extensional basin due to Indian slab rollback (DeCelles et al., 2011; Leary, DeCelles, et al., 2016). The successive burial and exhumation processes in the early Miocene have highlighted significant uncertainty regarding the surface geological evolution and mantle dynamics in the collision zone since the Oligocene (e.g., DeCelles et al., 2011; Husson et al., 2014; Leary, DeCelles, et al., 2016; Replumaz et al., 2010; Webb et al., 2017), which has renewed interest in the study of the geodynamics and mechanisms of the collision.

Disturbances in the subduction zone alter mantle flow, which in turn vertically deflects the surface of the Earth, thereby providing a simple mechanism to explain the formation of deep intracontinental basins (Husson et al., 2014; Webb et al., 2017). This process is commonly referred to as dynamic topography: viscously flowing mantle imposes vertical stresses underneath the lithosphere, and these stresses are counterbalanced by a dynamic deflection of the surface of the Earth (Husson et al., 2012). In regions where the structure of the mantle quickly evolves (typically subduction zones), transient dynamic topography is expected to respond efficiently and to be detectable in the geological record. Several theoretical (e.g., Gurnis \& Zhong, 1991; Husson et al., 2012) and case studies (e.g., Husson, 2006) point to kilometer-scale dynamic deflections in the topography above subduction zones. Such deflections are commonly transient, and the fast-changing Indian subduction dynamics are no exception. The northward motion of the Indian plate relative to its own slab (e.g., Replumaz et al., 2010; van der Voo et al., 1999) has been shown to be accompanied by a migration of the deflection above the mass anomaly in the mantle (Husson et al., 2014). At the surface, this process manifests as a southward migrating wave of subsidence followed by a southward migrating wave of uplift, already studied from the Himalaya toward the Ganges basin. These short-lived episodes explain both the Miocene surface uplift of the Himalaya and subsidence in the Ganges basin (Husson et al., 2014; Webb et al., 2017), as well as the formation of sedimentary basins on the NW Indian plate (Najman et al., 2018). This model offers a simple, single mechanism that explains a range of first-order observations. Thus, this interpretation represents an alternative to a more complex combination of processes involving removal of the mantle lithosphere (Harrison et al., 1992; Molnar et al., 1993), elastic flexure of the lithosphere (Lyon-Caen \& Molnar, 1983), and extension triggered by slab rollback (DeCelles et al., 2011; Leary, DeCelles, et al., 2016).

In this paper, we further test the dynamic topography model by exploring whether the predicted southward migrating waves of subsidence and uplift are recorded to the north of the Himalaya range and in southern Tibet. We revisit the spatial extent of the burial and exhumation experienced by the Kailas Formation and underlying rocks by reporting new in situ zircon fission track (ZFT) and apatite fission track (AFT) data and thermal modeling for the Gangdese batholith immediately to the north of the main preserved body of Kailas Formation rocks in the Mt. Kailas region in western Tibet. We focus on the succession of subsidence and exhumation and use numerical simulations to show that transient dynamic topography in response to mantle loading and unloading successfully reconciles structural, sedimentological, and thermochronological data in southern Tibet.

\section{Geological Settings}

\subsection{Regional Geology}

The Indus-Yarlung suture zone represents the site of the India-Asia continent-continent collision that began at circa $60 \mathrm{Ma}$ (e.g., DeCelles et al., 2014; Hu et al., 2016; Najman et al., 2010) and separates the Lhasa terrane to the north and the Tethyan Himalaya to the south (Yin \& Harrison, 2000). Late Jurassic and early Cretaceous volcano-sedimentary rocks are widely distributed to the north of the suture zone in the Lhasa terrane and are related to the northward subduction of the Neo-Tethys oceanic lithosphere (Zhu et al., 2011). The Gangdese magmatic arc is located along the southern margin of the Lhasa terrane (Figure 1) and is related to the end of oceanic subduction and removal of the slab at the onset of collision (e.g., Mahéo et al., 2002, 2009). This arc consists of the Linzizong volcanic rocks (with crystallization ages between $\sim 65$ and $45 \mathrm{Ma}$ ), the coeval Gangdese batholith (with crystallization ages between $\sim 60$ and $40 \mathrm{Ma}$ ) (Harrison et al., 2000; Mo et al., 2008, and references therein), and calc-alkaline and potassic-ultrapotassic volcanic rocks that formed in an Oligocene-Miocene stage (Chung et al., 2005). Some studies interpreted the last group of rocks as the products of a second slab breakoff, of the Indian lithosphere slab (e.g., Mahéo et al., 2002, 2009). Given the ages of the magmatic and volcanic rocks-K-Ar age of lamprophyres from the Karakorum range, 


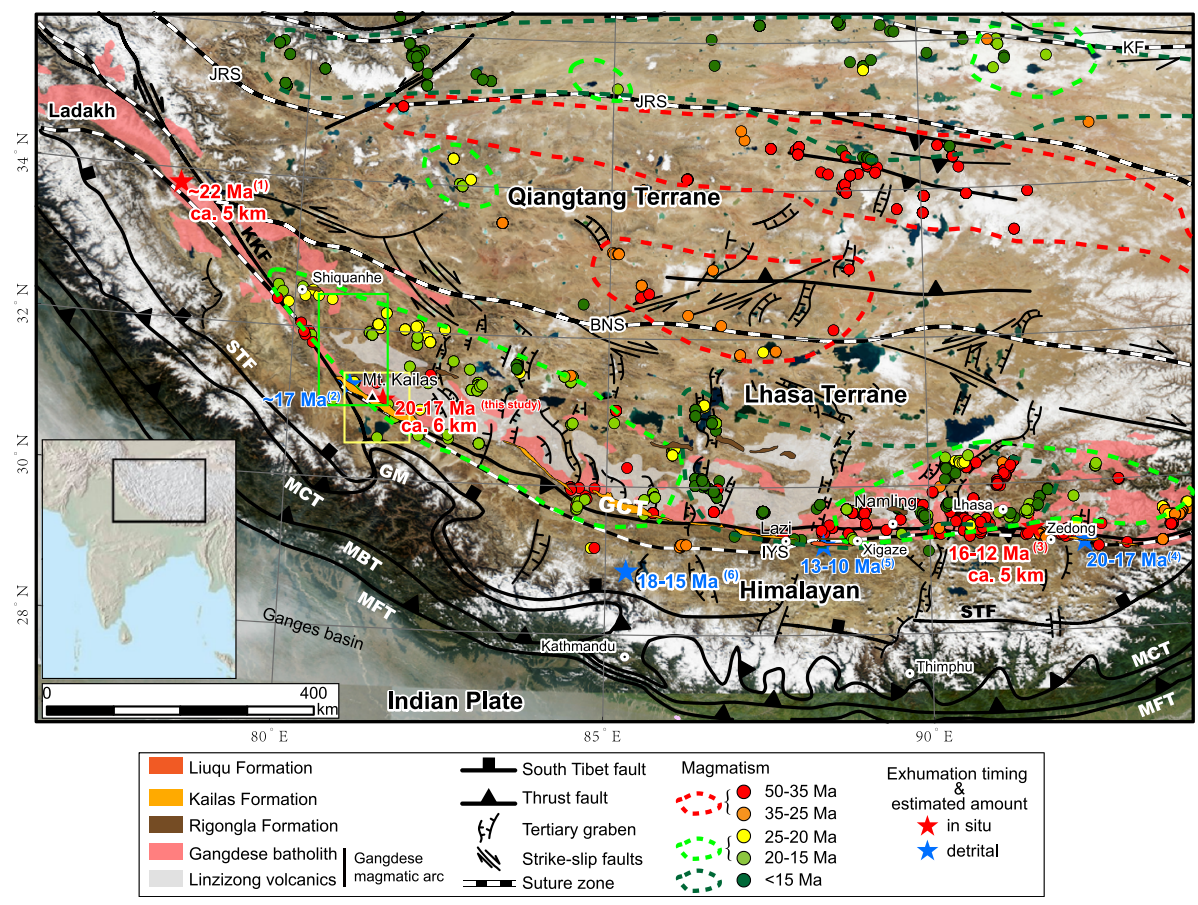

Figure 1. Schematic structural framework of southern Tibet and the Himalaya. Age data of magmatism are from the Tibetan Magmatism Database (https://www.jaychapman.org/tibet-magmatism-database.html) by Chapman and Kapp (2017), with contours from Goussin et al. (2020). Thermochronological data are cited from (1) Kirstein et al. (2006); (2) Carrapa et al. (2014); (3) Tremblay et al. (2015); (4) Li, Kohn, et al. (2015); (5) Li, Tian, et al. (2015); (6) Shen et al. (2016). The yellow box indicates the location of Figure 2, and the green box indicates the location of Figure 5. JRS = Jinsha suture; BNS = Banggong-Nujiang suture; IYS = Indus-Yarlung suture; GCT = Great Counter Thrust; $\mathrm{KF}=$ Kunlun Fault; KKF $=$ Karakorum Fault $;$ STF $=$ South Tibetan Fault; MCT $=$ Main Central Thrust $;$ MBT $=$ Main Boundary Thrust; MFT = Main Front Thrust; GM = Gurla Mandhata.

NE Pakistan (Rex et al., 1988); U-Pb and ${ }^{40} \mathrm{Ar} /{ }^{39} \mathrm{Ar}$ ages of adakitic volcanic rocks in western Tibet (Gourbet et al., 2017; Kapp et al., 2003; Miller et al., 1999; Williams et al., 2004); and the U-Pb age of an adakite in eastern Tibet (Zhang et al., 2014; Figure 1) - breakoff is thought to have initiated at $25 \mathrm{Ma}$ at the western and eastern ends of the slab (e.g., Husson et al., 2014; Replumaz et al., 2010; Webb et al., 2017).

The exhumation history of the Gangdese batholith has been highly debated over the past 20 years. In the eastern part of the batholith, near the city of Lhasa, ${ }^{40} \mathrm{Ar} /{ }^{39} \mathrm{Ar}$ thermochronological analyses have shown that the Gangdese batholith locally experienced two cooling stages, at 30-25 and 20-15 Ma (Harrison et al., 2000; Yin et al., 1999). They have been interpreted as due to upper crustal thickening, in between the southward thrusting along the GT (30-25 Ma) and northward thrusting along the Great Counter Thrust (GCT) (20-15 Ma), two major thrust faults described south of the Kailas Formation (Burg et al., 1987; Heim \& Gansser, 1939; Kapp et al., 2007; Ratschbacher et al., 1994; Yin et al., 1994, 1999). The north dipping GT is mainly exposed along the eastern part of the Indus-Yarlung suture zone (between the Zedong and Xigaze) and was active during the Oligocene (Yin et al., 1994, 1999). The south dipping GCT was active during 19-16 Ma (Harrison et al., 2000; Laskowski et al., 2017; Yin et al., 1999) and juxtaposed rocks associated with the Tethyan Himalaya, Gangdese forearc basin, and accretionary wedge atop the Gangdese magmatic arc and Kailas Formation (Murphy \& Yin, 2003; Yin et al., 1999). Low-temperature thermochronological analyses (fission track and [U-Th]/He) detected the second stage of cooling, which has been explained via a diverse range of interpretations, such as movement along the GT (Copeland et al., 1995), surface uplift (Carrapa et al., 2014; Tremblay et al., 2015), and north dipping duplex development beneath the Gangdese magmatic arc (Laskowski et al., 2018).

In western Tibet, the dextral Karakorum strike-slip fault has been shown to be a transpressive flower structure, producing thrusting in the south of the Kailas basin. The fault is connected to arc-perpendicular normal faults, such as the Xiao Gurla and Gurla Mandhata faults that have formed since 15 to 9 Ma (e.g., Carrapa 
et al., 2014; Chevalier et al., 2005; Lacassin et al., 2004; Murphy \& Yin, 2003; Pullen et al., 2011; Shen et al., 2016; Valli et al., 2007) (Figure 1). Along the southern front of the Himalaya, sole thrusts are propagating toward the foreland, forming an orogenic wedge, and include duplex systems associated with the Main Central Thrust (MCT, active during the early Miocene), the Main Boundary Thrust (MBT, active during the late Miocene), and the Main Frontal Thrust (MFT, active during the Quaternary) (e.g., Coutand et al., 2014; Kohn et al., 2001; Figure 1).

\subsection{Oligocene-Miocene Sedimentary Rocks Deposition Along the Gangdese Magmatic Arc}

Deposition of the Kailas Formation to the south of the magmatic arc occurred earlier in the west (near the Kailas peak) between 26 and $21 \mathrm{Ma}$, between 25 and $22 \mathrm{Ma}$ near Xigaze, and later eastward (near Zedong-Lhasa), between 23 and 18 Ma (Ai et al., 2019; DeCelles et al., 2011, 2018; Leary, DeCelles, et al., 2016). Detailed sedimentary analysis suggests that the formation in the Mt. Kailas area consists of a lower coarse-grained proximal conglomerate, a more distal fluvial sandstone member, a lacustrine shale and sandstone member, and an upper redbed clastic member (DeCelles et al., 2011). Most of the sediments were derived from the Gangdese magmatic arc to the north, with the exception of the uppermost redbed member (DeCelles et al., 2011; Leary, DeCelles, et al., 2016). Previous study suggested that the Kailas basin was never more than $20 \mathrm{~km}$ wide (DeCelles et al., 2011). However, several isolated outcrops of the formation are observed overlying the Gangdese batholith to the north of the present-day northern basin boundary (Figure 2), indicating that the Kailas Formation extended farther north than previously thought (Shen et al., 2019). The layers near the Mt. Kailas area are nearly horizontal, and the thickness of exposed stratigraphy is over 1,500 m (Ai et al., 2019; DeCelles et al., 2011; Shen et al., 2019). AFT and zircon (U-Th)/He ages from the Kailas Formation at the depth of $\sim 1,000 \mathrm{~m}$ in the stratigraphic column near the Kailas peak are younger than the depositional age and require between 4 and $7 \mathrm{~km}$ of burial followed by rapid cooling and exhumation starting at $17 \pm 1 \mathrm{Ma}$ with a cooling rate of $\sim 50^{\circ} \mathrm{C} / \mathrm{Myr}$ (Carrapa et al., 2014). The movement along the GCT deformed the southernmost fringe of the Kailas Formation (Yin et al., 1999). However, the subhorizontal stratigraphy of Mt. Kailas in the northern part of the basin also implies that crustal shortening and deformation have not affected the whole basin (e.g., DeCelles et al., 2011; Lacassin et al., 2004). Further east in the Xigaze area, the Kailas Formation is $~ 1,000 \mathrm{~m}$ thick (Leary, DeCelles, et al., 2016), and a thermochronologic study also suggests burial between 4 and $7 \mathrm{~km}$ after the deposition according to a granite sample beneath $900 \mathrm{~m}$ thick Kailas Formation (Ge et al., 2018).

South of the Indus-Yarlung suture zone, in the central part of southern Tibet, deposition continued to the early Miocene with the Liuqu Formation exposed near Xigaze (Leary, DeCelles, et al., 2016; Li, Tian, et al., 2015) (Figure 1). Leary, Orme, et al. (2016) suggested the Liuqu Formation represented a wedge-top basin of the northward thrusting of the GCT during or immediately after Indian slab breakoff, as contractional deformation resumed in the suture zone. However, clumped isotope thermometry of the Liuqu Formation revealed that it was buried between 2.9 and $3.3 \mathrm{~km}$ (Ning et al., 2019), followed by rapid exhumation between 12 and $10 \mathrm{Ma}$ (Li, Tian, et al., 2015), indicating similar subsidence and uplift processes as for the Kailas Formation.

Oligocene-Miocene deposition to the north of the Gangdese magmatic arc has been little discussed so far. The Rigongla Formation (Figure 1), with alluvial fan, fluvial-channel, and lacustrine facies, outcrops discontinuously at several locations within the central Lhasa terrane between Shiquanhe and Xigaze (Bai et al., 2018; Currie et al., 2016; Gourbet et al., 2017; Kapp et al., 2003; Wang et al., 2014; Wu, 1979; Zhang, Ducea, et al., 2014; Zhao et al., 2011; Zhu et al., 2006). The Rigongla Formation consists overall of an over 500-mthick fining-upward sequence of conglomerates, sandstones, and mudstones derived from the surrounding Cretaceous volcanic rocks (interbedded dacite to andesite) (Currie et al., 2016). Dacites in the lower Rigongla Formation yielded a K-Ar age of 31.4 Ma (Wang et al., 2014; Zhao et al., 2011), providing a maximum age of deposition for the unit. Vitrinite reflectance values indicate that the rocks were buried to maximum temperatures of $95-125^{\circ} \mathrm{C}$ (Currie et al., 2016), corresponding to a depth between 3 and $4 \mathrm{~km}$ with an estimated thermal gradient of $30^{\circ} \mathrm{C} / \mathrm{km}$.

\subsection{Controversies Associated With the Formation of the Kailas Basin}

Several models have been proposed for the tectonic context of the Kailas basin deposition based on geological observations, all with major shortcomings or inconsistencies. Yin et al. (1999) suggest that the Kailas Formation was deposited in a foreland basin system related to the uplift and erosion of the Gangdese 


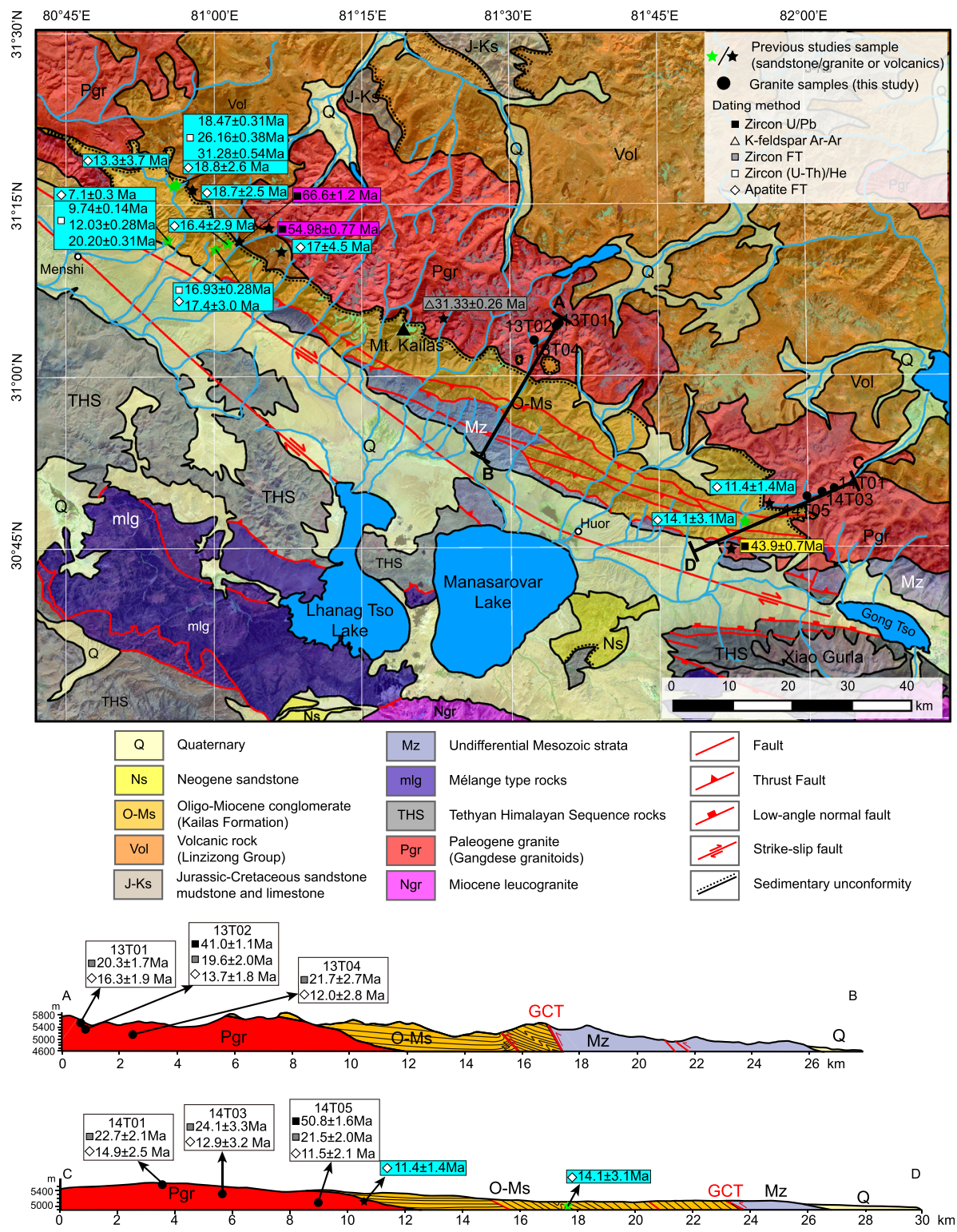

Figure 2. Detailed geological map of the Mt. Kailas area, showing the sample locations and previous thermochronological data in study area: Gray, Yin et al. (1999); violet, DeCelles et al. (2011); yellow, Pullen et al. (2011); and cyan, Carrapa et al. (2014). Cross sections with sample locations are shown below the map.

magmatic arc to the north of the basin. The basin was uplifted by the top-to-the-south GT below the batholith, which is blind in the Kailas region but emergent to the east in the Zedong region, possibly active between 31 and $24 \mathrm{Ma}$ (Harrison et al., 2000; Yin et al., 1999). Both the absence of the GT in the Mt. Kailas region and the proposed timing for the onset of the fault (5 Ma earlier than the deposition of the Kailas Formation) argue against this model. Wang et al. (2015) proposed another compressional model, which interpreted the basin as a flexural foredeep basin loaded, to the south in this case, by the top-to-the-north GCT, which bounded the basin to the south. However, the onset of the GCT (19-16 Ma) after the main deposition phase of the Kailas Formation (26-21 Ma), as well as the northern provenance of the sediments, challenge this interpretation (DeCelles et al., 2011; Laskowski et al., 2017).

Finally, based on sedimentary and thermochronology studies, it has been suggested that the Kailas Formation was deposited in an extensional context during relative southward rollback of the Indian slab below southern Tibet prior to Miocene slab breakoff (Carrapa et al., 2014; DeCelles et al., 2011; Laskowski 

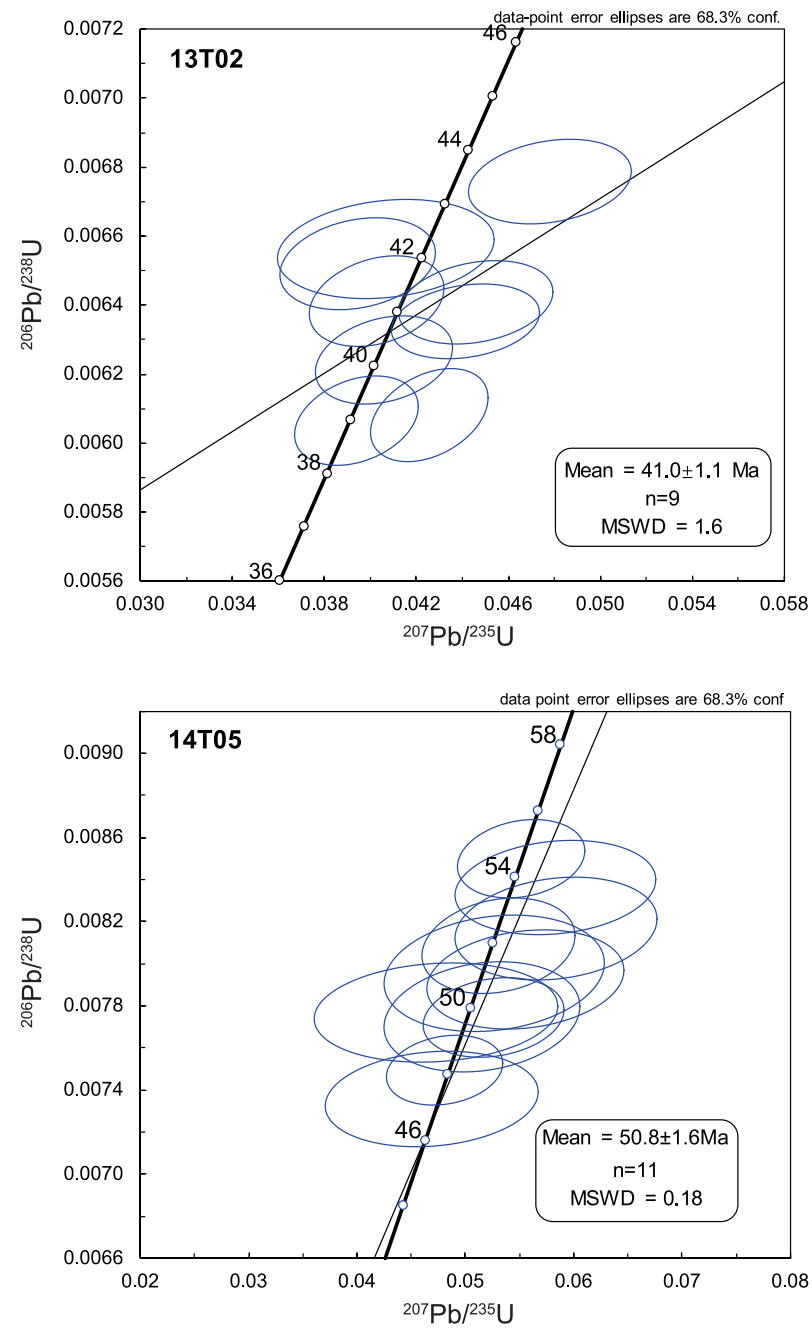

Figure 3. U-Pb concordia diagrams of Samples $13 \mathrm{~T} 02$ (top) and $14 \mathrm{~T} 05$ (bottom) using the program Isoplot (Ludwig, 2012). The data reduction procedures are described in Liu et al. $(2008,2010)$ with GJ-1 zircon standards (Jackson et al., 2004). et al., 2017; Leary, DeCelles, et al., 2016; Webb et al., 2017). In this model, the northern edge of the Indian slab reached the northern Lhasa terrane between 30 and 26 Myr ago (DeCelles et al., 2011; Kapp \& DeCelles, 2019). The subsequent, long-range slab rollback is interpreted to be represented by a coeval southward migration of volcanism across the Lhasa terrane. During sediment deposition, the Kailas basin would have been bounded to the south by a normal fault and was later disrupted by thrusting on the GCT. The Kailas basin was then subsequently exhumed in response to renewed Indian plate underthrusting following slab detachment. However, at the scale of the Tibetan plateau, there are only three volcanic belts (Chung et al., 2005), which have been interpreted as related to subduction events. The main belt is the Gangdese magmatic arc following the Indus-Yarlung suture, related to the northward subduction of the Indian plate. Another belt is following the Jinsha suture, related to the southward subduction of the Asian lithosphere in an early phase of collision (e.g., Goussin et al., 2020; Horton et al., 2002; Spurlin et al., 2005). Finally, one belt follows the Kunlun suture, related to ongoing southward Asian lithosphere subduction since $\sim 15 \mathrm{Ma}$ (Figure 1). In between the Indus-Yarlung and the Jinsha sutures, volcanism is sparse in the Qiangtang and the Lhasa terranes, where its spatial pattern does not appear consistent with a continuous southward migration wave associate to a slab rollback (Figure 1). Furthermore, this scenario relies on unsupported geodynamic and structural inferences and unlikely mechanical behavior. Structurally, the extensional setting is only indirectly inferred from the large-scale architecture of the basin, which is interpreted as growth strata. No clear evidence of normal faulting is reported (Leary, DeCelles, et al., 2016). The mechanical impact of slab rollback within a sustained collisional setting, as advocated in this model, may be misinterpreted. While the slab continued to roll back during the deposition of the Kailas Formation, the still-converging Indian and Eurasian plates sustained compression in the Himalaya and potentially caused extension in the mantle wedge above the slab. Only compression-not extension-is expected between the colliding lithospheres (Pitard et al., 2018; Replumaz et al., 2016). Therefore, both the absence of unambiguous extensional structures and a problematic geodynamic framework weaken this interpretation.

\section{Thermochronology}

\subsection{Samples and Dating Results}

We collected six bedrock samples from the Gangdese batholith along two transects, one $20 \mathrm{~km}$ and another $\sim 80 \mathrm{~km}$ east of Mt. Kailas (Figure 2), for AFT, ZFT, and zircon U-Pb dating. Detailed analytical procedures for zircon $\mathrm{U}-\mathrm{Pb}, \mathrm{ZFT}$, and AFT dating are presented in the Text $\mathrm{S} 1$ in the supporting information. The zircon $\mathrm{U}-\mathrm{Pb}$ ages are $41.0 \pm 1.1 \mathrm{Ma}(13 \mathrm{~T} 02)$ and $50.8 \pm 1.6 \mathrm{Ma}$ (14 T05) (see Table S1 for details), with Pb/U concordia diagrams created using Isoplot (v. 3.75) (Ludwig, 2012) shown in Figure 3. ZFT analysis yielded cooling ages between $19.6 \pm 2.0$ and $24.1 \pm 3.3 \mathrm{Ma}( \pm 2 \sigma)$ (Table 1), and AFT analysis yielded cooling ages between $16.3 \pm 1.9$ and $11.5 \pm 2.1 \mathrm{Ma}( \pm 2 \sigma)$ (Table 3 ). Detailed fission track data are provided in Supporting Information S1. These ages do not show significant correlation with sample elevation (Figure 4a). For samples 13T01 and 13T02, 135 and 77 apatite confined track lengths are measured (Table 3), providing mean AFT $c$ axis projected length of $13.89 \pm 1.32$ and $13.74 \pm 1.38 \mu \mathrm{m}$ (with 1 standard deviation), respectively. The samples 14T01 and 14T05 each yielded less than 50 measured track lengths, with mean values of $14.22 \pm 1.09$ and $14.59 \pm 1.14 \mu \mathrm{m}$.

One modern river sand sample was collected to the north of the Gangdese magmatic arc, approximately $90 \mathrm{~km}$ east of Shiquanhe (Figure 5), and subjected to ZFT analysis. The river originated from the Mt. 
Table 1

Thermal History Input Table for the QTQt Modeling

1. Thermochronologic Data

Samples and data used in modeling

\begin{tabular}{lcc}
\hline Sample & AFT ages & AFT lengths \\
\hline 13 T01 & $\mathrm{X}$ & $\mathrm{X}$ \\
13 T02 & $\mathrm{X}$ & $\mathrm{X}$ \\
13 T04 & $\mathrm{X}$ & $\mathrm{X}$ \\
\hline
\end{tabular}

Data treatment

The AFT lengths are measured from cf tracks and using c-axis projected lengths (Ketcham et al., 2007), with initial track length of $16.3 \mu \mathrm{m}$. The term for the kinetic parameter is Dpar (Donelick et al., 1999; Ketcham et al., 1999).

The AFT ages and lengths are combined in one data set for an individual sample, while the ZFT ages were regarded as another data input file for the same sample, with the same GPS information but different annealing parameters.

These data were modeled as an age-elevation profile.

\section{Additional geologic information}

Assumption
At a surface temperature of $0 \pm 10^{\circ} \mathrm{C}$ by $0 \mathrm{Ma}$
At a near-surface level during $32-26 \mathrm{Ma}$, assuming a temperature of 200
$\quad \pm 200^{\circ} \mathrm{C}$

\section{Explanation and data source}

Based on the annual mean surface temperature of the Tibetan Plateau for the years from 1961 to 2000 (Yang et al., 2010)

The Gangdese batholith was exposed at the surface before deposition of the Kailas Formation (Carrapa et al., 2014; DeCelles et al., 2011). Available 40Ar/39Ar ages of $\mathrm{K}$-feldspar for the Gangdese batholith in the Mt. Kailas area, close to our profile $(\sim 15 \mathrm{~km}$ to the west), suggest that the rocks experienced cooling after $32 \mathrm{Ma}$ (Yin et al., 1999).

Modeling begins at temperatures of $750-850^{\circ} \mathrm{C}$ at $41.0 \pm 1.1 \mathrm{Ma}$

\footnotetext{
3. System- and model-specific parameters

AFT annealing model: Ketcham et al. (2007)

ZFT annealing model: Yamada et al. (2007) long term

Modeling Code: QTQt version 5.5.0 for PC user

Inversion scheme: Bayesian transdimensional Markov chain Monte Carlo (MCMC)

Ranges for general prior:

Time (Myr): oldest observed age \pm oldest observed age (i.e., $24.1 \pm 24.1$ Ma here)

Temperature $\left({ }^{\circ} \mathrm{C}\right): 200 \pm 200$

Maximum $\partial \mathrm{T} / \partial \mathrm{t}\left({ }^{\circ} \mathrm{C} / \mathrm{Myr}\right): 1000$

MCMC parameters:

Burn-in: 50,000 iterations; post-burn-in: 200,000 iterations.
}

Table 2

Bedrock ZFT Results From the Gangdese Batholith

\begin{tabular}{|c|c|c|c|c|c|c|c|c|c|c|c|c|c|c|}
\hline No. & GPS & $\begin{array}{l}\text { Elevation } \\
(\mathrm{m})\end{array}$ & Lithology & $\rho_{s}$ & $N_{S}$ & $\rho_{i}$ & $N_{i}$ & $\rho_{d}$ & $N_{d}$ & $N$ & $P\left(\chi^{2}\right)$ & Dispersion & $\begin{array}{c}\text { Pooled } \\
\text { age (Ma) }\end{array}$ & $\begin{array}{l}\mathrm{U} \pm 2 \sigma \\
(\mathrm{ppm})\end{array}$ \\
\hline 13T01 & $\begin{array}{l}81.58389 \\
31.08029\end{array}$ & 5,447 & Granite & $8.11 \times 10^{6}$ & 1,581 & $6.35 \times 10^{6}$ & 1,239 & $2.54 \times 10^{5}$ & 3,161 & 20 & $80.4 \%$ & $1.2 \%$ & $20.3 \pm 1.7$ & $1,253 \pm 78$ \\
\hline 13T02 & $\begin{array}{l}81.58159 \\
31.07923\end{array}$ & 5,317 & Granite & $6.10 \times 10^{6}$ & 992 & $4.94 \times 10^{6}$ & 804 & $2.54 \times 10^{5}$ & 3,161 & 20 & $65.7 \%$ & $1.0 \%$ & $19.6 \pm 2.0$ & $974 \pm 73$ \\
\hline 13Т04 & $\begin{array}{l}81.53824 \\
31.04565\end{array}$ & 5,044 & Granite & $3.54 \times 10^{6}$ & 647 & $2.60 \times 10^{6}$ & 475 & $2.54 \times 10^{5}$ & 3,161 & 19 & $97.6 \%$ & $0.3 \%$ & $21.7 \pm 2.7$ & $513 \pm 49$ \\
\hline $14 \mathrm{~T} 01$ & $\begin{array}{l}82.05073 \\
30.83476\end{array}$ & 5,493 & Diorite & $5.43 \times 10^{6}$ & 1,324 & $3.79 \times 10^{6}$ & 926 & $2.54 \times 10^{5}$ & 3,161 & 20 & $98.4 \%$ & $0.2 \%$ & $22.7 \pm 2.1$ & $748 \pm 53$ \\
\hline $14 \mathrm{~T} 03$ & $\begin{array}{l}82.02802 \\
30.83046\end{array}$ & 5,291 & Diorite & $2.78 \times 10^{6}$ & 550 & $1.83 \times 10^{6}$ & 362 & $2.54 \times 10^{5}$ & 3,161 & 18 & $88.6 \%$ & $0.6 \%$ & $24.1 \pm 3.3$ & $361 \pm 39$ \\
\hline $14 \mathrm{~T} 05$ & $\begin{array}{l}82.00145 \\
30.82388\end{array}$ & 5,104 & Diorite & $5.50 \times 10^{6}$ & 1,197 & $4.08 \times 10^{6}$ & 887 & $2.54 \times 10^{5}$ & 3,162 & 20 & $98.1 \%$ & $0.4 \%$ & $21.5 \pm 2.0$ & $805 \pm 58$ \\
\hline
\end{tabular}

Note. All the samples were counted with a zeta calibration factor (Hurford \& Green, 1982) $\xi=125.66 \pm 1.86$ for glass dosimeter IRMM541. $N=$ total number of grains counted; binomial peak-ages are given \pm 2 SE. The percentage of grains in a specific peak is also given. $P\left(\chi^{2}\right), \chi^{2}$ probability that the single grain ages represent one population. 
Table 3

Bedrock AFT Results From the Gangdese Batholith

\begin{tabular}{|c|c|c|c|c|c|c|c|c|c|c|c|c|c|c|}
\hline No. & $\rho_{s}$ & $N_{S}$ & $\rho_{i}$ & $N_{i}$ & $\rho_{d}$ & $N_{d}$ & $N$ & $P\left(\chi^{2}\right)$ & Dispersion & $\begin{array}{l}\text { Pooled age } \\
\text { (Ma) }\end{array}$ & $\begin{array}{l}\mathrm{U} \pm 2 \sigma \\
(\mathrm{ppm})\end{array}$ & $n$ & $\operatorname{MTL}(\mu \mathrm{m})$ & $\operatorname{MTLc}(\mu \mathrm{m})$ \\
\hline $13 \mathrm{~T} 01$ & $3.50 \times 10^{5}$ & 403 & $2.83 \times 10^{6}$ & 3,256 & $1.07 \times 10^{6}$ & 3,394 & 20 & $98.0 \%$ & $0.2 \%$ & $16.3 \pm 1.9$ & $40 \pm 2$ & 135 & $12.70 \pm 1.83$ & $13.89 \pm 1.32$ \\
\hline $13 \mathrm{~T} 02$ & $2.31 \times 10^{5}$ & 275 & $2.24 \times 10^{6}$ & 2,664 & $1.07 \times 10^{5}$ & 3,405 & 20 & $91.9 \%$ & $0.3 \%$ & $13.7 \pm 1.8$ & $31 \pm 2$ & 77 & $12.60 \pm 1.87$ & $13.74 \pm 1.38$ \\
\hline $13 \mathrm{~T} 04$ & $9.77 \times 10^{4}$ & 84 & $1.08 \times 10^{6}$ & 926 & $1.07 \times 10^{6}$ & 3,417 & 20 & $99.0 \%$ & $0.1 \%$ & $12.0 \pm 2.8$ & $15 \pm 1$ & & & \\
\hline 14T01 & $1.31 \times 10^{5}$ & 162 & $1.18 \times 10^{6}$ & 1,451 & $1.08 \times 10^{6}$ & 3,428 & 24 & $75.7 \%$ & $1.6 \%$ & $14.9 \pm 2.5$ & $16 \pm 1$ & 41 & $13.13 \pm 1.57$ & $14.22 \pm 1.09$ \\
\hline $14 \mathrm{~T} 03$ & $1.46 \times 10^{5}$ & 72 & $1.51 \times 10^{6}$ & 745 & $1.08 \times 10^{6}$ & 3,440 & 21 & $100.0 \%$ & $0.1 \%$ & $12.9 \pm 3.2$ & $21 \pm 2$ & & & \\
\hline $14 \mathrm{~T} 05$ & $1.43 \times 10^{5}$ & 141 & $1.67 \times 10^{6}$ & 1,648 & $1.08 \times 10^{6}$ & 3,451 & 30 & $99.9 \%$ & $0.1 \%$ & $11.5 \pm 2.1$ & $23 \pm 1$ & 37 & $13.76 \pm 1.54$ & $14.59 \pm 1.14$ \\
\hline
\end{tabular}

Note. All the samples were counted with a zeta calibration factor $\xi=247.47 \pm 6.05$ for glass dosimeter IRMM540R. $N=$ total number of grains counted; binomial peak-ages are given $\pm 2 \mathrm{SE}$. The percentage of grains in a specific peak is also given. $P\left(\chi^{2}\right), \chi^{2}$ probability that the single grain ages represent one population. $n=$ number of horizontal confined track length measured; MTL = mean track length (with \pm 1 Std. Dev., standard deviation). MTLc $=$ mean track length of $c$ axis projected. All apatite samples for track length measurements were irradiated by a collimated beam of heavy ions released from a $252 \mathrm{Cf}$ source at the University of Melbourne (Australia) (Donelick \& Miller, 1991).

Kailas area to the south, running mostly northward through the Linzizong volcanic rocks and belonging to the Indus drainage system. The Linzizong volcanic rocks cover most of the drainage area; therefore, the sediment sample could be used to reveal the long-term exhumation history of the Linzizong volcanic rocks in the northern part of the Gangdese magmatic arc. Central and peak ages of the sample are determined and plotted with the RadialPlotter by Vermeesch (2009) and presented in Table 4 and Figure 5. The detrital ZFT grains ages range from 15.0 to $96.0 \mathrm{Ma}$, and three peak ages of $27.3 \pm 1.3$, $40.5 \pm 2.3$ and $70.0 \pm 8.1$ Ma are obtained.

\subsection{Thermochronological Modeling}

Fission track data, including AFT ages, AFT lengths, and ZFT ages, are modeled using the QTQt software (v. 5.5.0) (Gallagher, 2012) to extract thermal history models. We only performed modeling for samples from the western transect (Sample 13T series) because samples from the other transect provided insufficient AFT length data for modeling. The two zircon $\mathrm{U}-\mathrm{Pb}$ ages from the Gangdese batholith of $41.0 \pm 1.1 \mathrm{Ma}(13 \mathrm{~T} 02)$ and $50.8 \pm 1.6 \mathrm{Ma}$ (14 T05), interpreted as the age of the batholith intrusion and crystallization, have been introduced into the model as a thermal constraint of $750 \pm 100^{\circ} \mathrm{C}$ (Harrison et al., 2007; Valley et al., 2006) between 50 and $40 \mathrm{Ma}$. The fact that the Kailas Formation was deposited unconformably on the granite means that the top of the batholith was at the surface before deposition started, that is, at $\sim 26 \mathrm{Ma}$ at the location of the Kailas basin (DeCelles et al., 2011). This condition has been introduced as a second thermal constraint with a low temperature $\left(0-400^{\circ} \mathrm{C}\right)$ between 32 and $26 \mathrm{Ma}$ to take into account the shallow depth range of the samples before Kailas Formation deposition (Table 1 and Figure 4b) and the present-day surface temperature of $0 \pm 10^{\circ} \mathrm{C}$ (mean annual surface temperature from 1961 to 2000 on the Tibetan Plateau; Yang et al., 2010).

After discarding the initial 50,000 burn-in iterations, 200,000 iterations of the model are run. For fission track annealing kinetics, the multikinetic annealing model of Ketcham et al. (2007) was chosen for AFT data, and the kinetics of Yamada et al. (2007) are chosen for ZFT data. Compositionally dependent initial track lengths are calculated based on a Dpar value for each apatite grain, calibrated against the Durango apatite standard. Detailed QTQt modeling parameters are shown in Table 1, and all the data used for QTQt modeling are shown in Supporting Information S2. The Eocene postmagmatic cooling is constrained by the two thermal constraints imposed on the model, resulting in rapid cooling between $\sim 40$ and $\sim 28 \mathrm{Ma}$, compatible with the published K-feldspar ${ }^{40} \mathrm{Ar} /{ }^{39} \mathrm{Ar}$ age of $31.33 \pm 0.26 \mathrm{Ma}$ (Figure $4 \mathrm{a}$ ) from the nearby granite Sample 95-6-11 (Figure 2) (Yin et al., 1999). For the fission track data, the best fit inversion model obtained with QTQt shows a three-stage thermal history (Figure $4 \mathrm{~b})$ : (1) heating from $\sim 200^{\circ} \mathrm{C}\left(60-350^{\circ} \mathrm{C}\right.$ with $95 \%$ confidence interval) to $\sim 380^{\circ} \mathrm{C}\left(320-420^{\circ} \mathrm{C}\right.$ with $95 \%$ confidence interval) between $\sim 28-26$ and $\sim 20 \mathrm{Ma}$ (16- $\left.\backslash 40^{\circ} \mathrm{C} / \mathrm{Myr}\right)$, (2) rapid cooling from $\sim 380^{\circ} \mathrm{C}\left(320-420^{\circ} \mathrm{C}\right.$ with $95 \%$ confidence interval) to $\sim 100^{\circ} \mathrm{C}$ (30- $120^{\circ} \mathrm{C}$ with $95 \%$ confidence interval) between $21-20$ and $17 \mathrm{Ma}$ with a minimum cooling rate of $\sim 50^{\circ} \mathrm{C} / \mathrm{Myr}$, and (3) relatively slow cooling since $\sim 6 \mathrm{Ma}$ after an $\sim 10 \mathrm{Myr}$ residence time in the AFT partial annealing zone. The model-predicted ages and track length are plotted in Figure 4c, and the individual sample predictions by QTQt are provided in Supporting Information S2. 

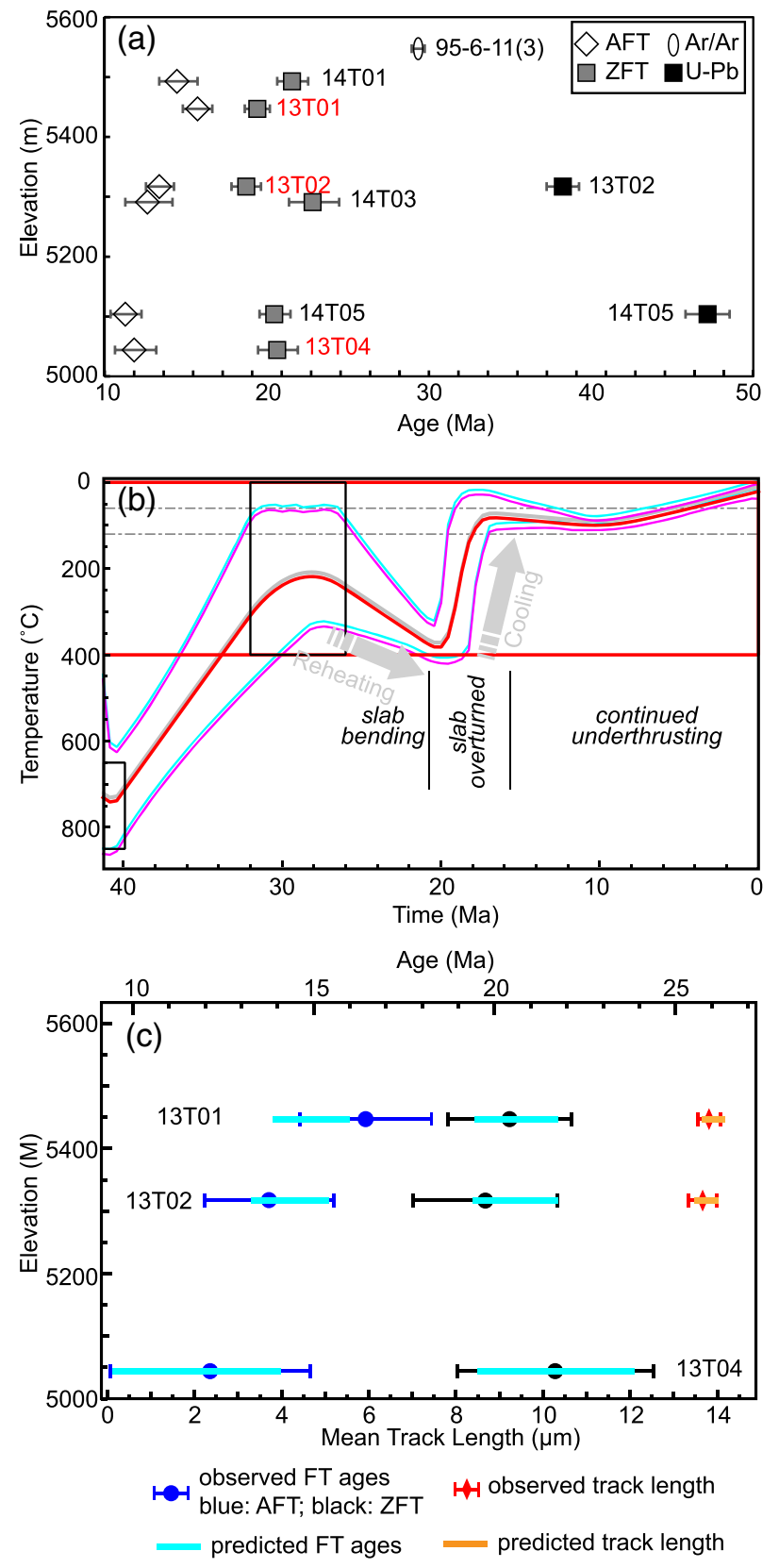

Figure 4. (a) Age-elevation plots for dated samples and selected previous ${ }^{40} \mathrm{Ar} /{ }^{39} \mathrm{Ar}$ datum (Yin et al., 1999). Samples with red labels are used for QTQt modeling. (b) QTQt model results taking Samples 13T01, $13 \mathrm{~T} 02$, and $13 \mathrm{~T} 04$ as a profile. The red line corresponds to the path of the hottest (lowest elevation) sample (with the $95 \%$ credible interval range in magenta); the blue line corresponds to the coolest (highest elevation) sample (with the $95 \%$ credible interval range in cyan); intermediate samples are shown in gray. (c) The predicted data by the QTQt modeling compared with observed data. The red box is the general prior time-temperature box, which was set to a temperature of $200 \pm 200^{\circ} \mathrm{C}$ (Ketcham et al., 2007), and the black boxes are geological constraints on the modeling (see the text and Table 1 for details).

\section{Dynamic Topography Modeling}

We modeled changes in dynamic topography to decipher the link between first-order geomorphic changes and deep slab movements. We model the viscous flow beneath the Indian-Eurasian convergence zone following the Stokeslets approximation (Harper, 1984; Morgan, 1965), which has proven successful in global (e.g., Ricard et al., 1993) and more regional (Guillaume et al., 2009) models. The density field is discretized into point masses, and each point mass $i$ induces an elementary flow for which the stream function is known (e.g., Batchelor, 1967), which can be written as follows:

$$
\Psi_{i}=\frac{\Delta \rho v_{i} g}{8 \pi \eta} r_{i j} \sin ^{2} \theta_{i j}
$$

where $\Delta \rho v_{i}$ is the mass anomaly associated with each point mass, $g$ is the acceleration of gravity, $\eta$ is the viscosity, $r_{i j}$ is the distance from the point mass $i$ to a point $j$ at the surface, and $\theta_{i j}$ is the angle between the vector $i j$ and $g$. The normal stress is computed following the image technique, as in Morgan (1965):

$$
F_{i j}=\frac{3 \Delta \rho v_{i} g z_{i}^{3}}{\pi r_{i j}^{5}}
$$

where $z_{i}$ is the depth of the point mass. For a stress-free surface, the normal stress is compensated by an opposite surface load. That surface load is a deflection of the surface (dynamic topography):

$$
h_{i j}=\frac{F_{i j}}{\left(\rho_{m}-\rho\right) g}
$$

where $\rho_{m}$ is the density of the mantle and $\rho$ is the density of water in immersed domains, air in subaerial domains (as in the Himalaya for instance), or sediments in sedimentary plains (such as the Indo-Gangetic plain). The total deflection $H_{i j}$ is the sum of all individual deflections, and the dynamic topography at a given location is given by the following:

$$
H_{i j}=\frac{3 \Delta \rho v_{i} \mathrm{~g} z_{i}^{3}}{\pi r_{i j}^{5}\left(\rho_{m}-\rho\right)} .
$$

Here, we take advantage of this semianalytical formalism to explore the dynamic topography (as in Husson, 2006) above a flowing mantle around reconstructed idealized slab geometries.

We computed models of dynamic topography from our reconstructed geometries at intervals of $5 \mathrm{Myr}$, and only updating the slab geometry between 30 and $25 \mathrm{Ma}$ in order to account for shortening and slab relocation beneath the Himalaya. Slab geometries at each time are reconstructed as described in Husson et al. (2014) and Webb et al. (2017), based on geophysical observations for present day, and geological arguments for past reconstructions in the past complemented by lessons from numerical and analog models. In practice, slab geometries are simplified as downdipping surfaces. Slabs are linear at the surface and distorted at depth. That distortion is defined by a laterally variable dip along the trench. Over time, the slab overall rotates from a north dipping to a south dipping slab over $25 \mathrm{Myr}$ period. In addition, the slab gradually detaches from the edges toward the center over the same period. Last, the slab is offset with respect to the 


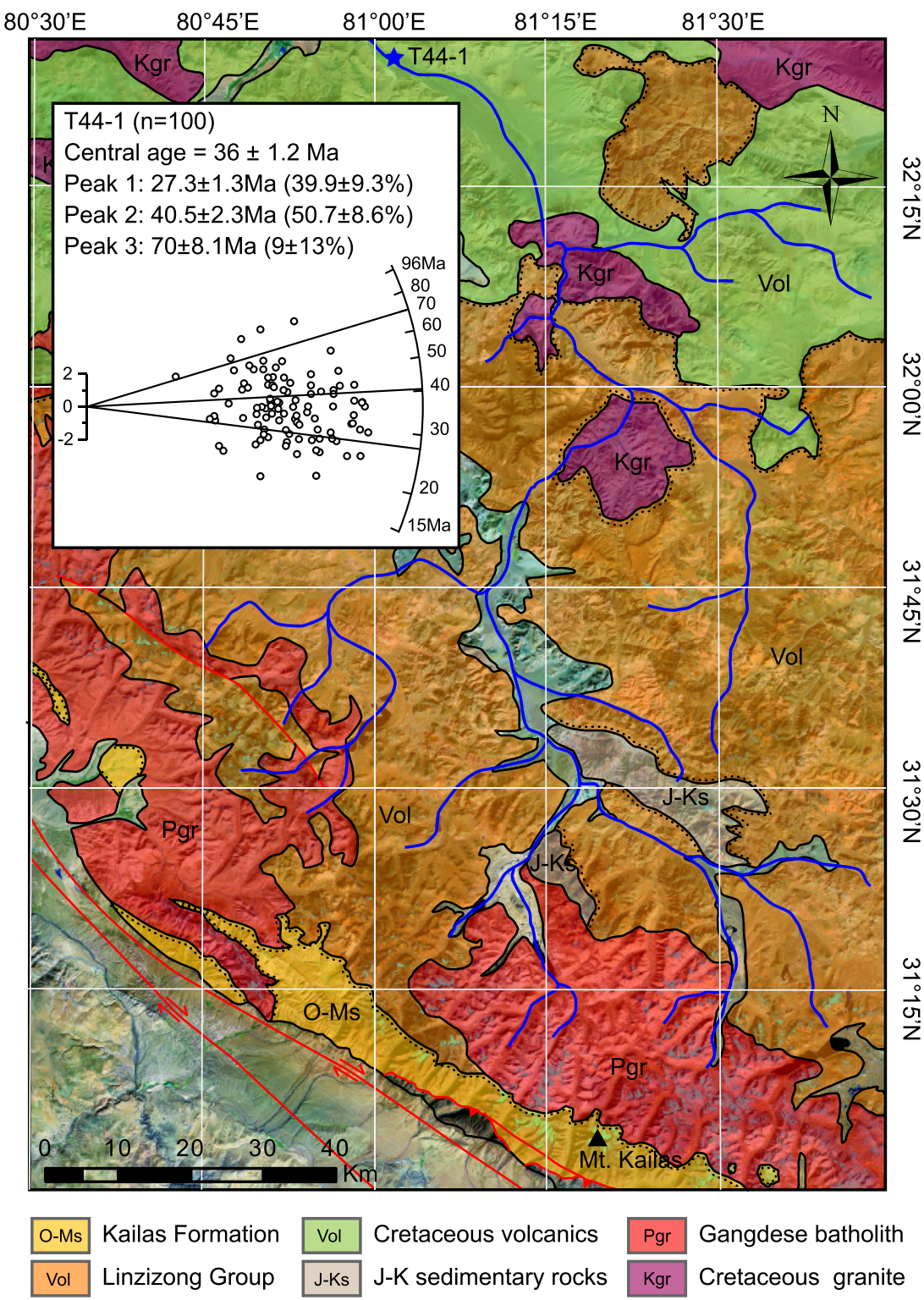

Figure 5. Drainage network related to the modern river sand sample (red star). Main lithologic units of the northern Gangdese magmatic arc are shown in the figure. Inset figure illustrates the RadialPlotter plot of the ZFT data from the modern river sand.

trench, by an amount that decreases over time, to account for relative rollback. Detailed geometries are accessible in Husson et al. (2014).

Slabs at each time step are discretized into individual Stokeslets (or point masses). The negative buoyancy of the slab at any time is computed assuming that an unstretched section of slab has a thickness of $110 \mathrm{~km}$ and a

Table 4

Detrital Zircon Fission Track Data From Sample T44-1

\begin{tabular}{|c|c|c|c|c|c|c|c|c|c|c|c|c|c|}
\hline $\begin{array}{l}\text { Sample } \\
\text { no. }\end{array}$ & $\begin{array}{c}\text { GPS } \\
\text { location }\end{array}$ & $N$ & $\begin{array}{c}\rho_{d} \times 10^{5} \mathrm{~cm}^{-2} \\
\left(\mathrm{~N}_{\mathrm{d}}\right)\end{array}$ & $\begin{array}{c}\rho_{S} \times 10^{6} \mathrm{~cm}^{-2} \\
\left(\mathrm{~N}_{\mathrm{S}}\right)\end{array}$ & $\begin{array}{c}\rho_{i} \times 10^{6} \mathrm{~cm}^{-2} \\
\left(\mathrm{~N}_{\mathrm{i}}\right)\end{array}$ & $\frac{\mathrm{U}}{\left(\mathrm{ug} \cdot \mathrm{g}^{-1}\right)}$ & $P\left(\chi^{2}\right)$ & Dispersion & $\begin{array}{c}\text { Age } \\
\text { range } \\
(\mathrm{Ma})\end{array}$ & $\begin{array}{c}\text { P1 age } \\
(\mathrm{Ma} \pm 1 \sigma)\end{array}$ & $\begin{array}{c}\text { P2 age } \\
(\mathrm{Ma} \pm 1 \sigma)\end{array}$ & $\begin{array}{c}\text { P3 age } \\
(\mathrm{Ma} \pm 1 \sigma)\end{array}$ & $\begin{array}{l}\text { Central age } \\
(\mathrm{Ma} \pm 1 \sigma)\end{array}$ \\
\hline T44-1 & $\begin{array}{l}81.08881 \\
32.39525\end{array}$ & 100 & $3.837(2686)$ & $4.17(3,689)$ & $3.02(2,669)$ & 313 & 0 & $28 \%$ & $15.0-96.0$ & $\begin{array}{c}27.3 \pm 1.3 \\
(39.9 \pm 9.3 \%)\end{array}$ & $\begin{array}{c}40.5 \pm 2.3 \\
(50.7 \pm 8.6 \%)\end{array}$ & $\begin{array}{l}70 \pm 8.1 \\
(9 \pm 13 \%)\end{array}$ & $36.0 \pm 1.2$ \\
\hline
\end{tabular}


density contrast with the mantle of $60 \mathrm{~kg} \mathrm{~m}^{-3}$. The total buoyancy of the slab in the upper mantle is assumed to be uniform per unit trench length at each time step. Because the lithosphere stretches as it gets closer to the edges, its thickness decreases. Thus, the absolute buoyancy of the individual point masses decreases, and we adjust the values accordingly. In these models, we only consider the density anomaly of the slab; hence, the net density anomaly is positive. This implicitly corresponds to the assumptions that opposing buoyancy anomalies (to restore a neutral net buoyancy) are either uniformly distributed in the mantle or too remotely located to produce any effect in the area. In both cases, there is no impact on the model predictions. Summing up individual flows of each Stokeslet yields the entire flow, from which the vertical stress beneath the surface can be computed.

The vertical stress is compensated by a long-wavelength (100 s of $\mathrm{km}$ ) deflection, either filled with air, sediments, or water. This is critical because the magnitude of the deflection scales with the density contrast between the mantle and the filling material, namely, sediments in the Indo-Ganges plain and Kailas basin (corresponding to a density contrast of $500 \mathrm{~kg} \mathrm{~m}^{-3}$ ) and air in the Himalayan belt (corresponding to a density contrast of 3,200 $\mathrm{kg} \mathrm{m}^{-3}$ ). Note that the deflection has a very low aspect ratio (amplitude over wavelength), which implies that its geometry remains insensitive to the elasticity of the lithosphere, regardless of its compensation. We therefore predict air-compensated deflections $\delta z a$ and sediment-compensated deflections $\delta z s$ (and their temporal variations, i.e., uplift and subsidence; Figure 6). Because air-compensated topographic change by default assumes no erosion, we also computed the values of surface uplift with an amount of equivalent erosion in order for the elevation to remain constant throughout while maintaining isostasy. This scenario represents the maximum bound for bulk exhumation of the Gangdese batholith and Kailas basin caused by dynamic surface uplift.

As the slab remains stationary underneath the northward drifting Indian plate, our model predicts a wave of dynamic subsidence migrating from the Lhasa terrane to the south (from 30 to $26 \mathrm{Ma}$; Figure 6) toward its current southern location, where it now explains the deflection of the foreland basin (see also Husson et al., 2014). If compensated by sediments, as we hypothesize for the Kailas basin, the predicted deflection amounts to about 4 to $7 \mathrm{~km}$ (note that it would be only $\sim 1 \mathrm{~km}$ in the absence of sedimentary infill, that is, if the stresses were compensated by air instead of sediments). As the slab migrates southward relative to the Himalaya, the mantle load and dynamic deflection relocate southward and the topography bounces back. In the absence of erosion, our model predicts a surface uplift of $\sim 1 \mathrm{~km}$. If this surface uplift were instantaneously compensated by erosion, the amount of rock uplift could be as high as $5-6 \mathrm{~km}$.

\section{Discussion: Dynamic Subsidence and Surface Uplift in Southernmost Tibet}

Multiple unrelated processes have been invoked in the past to explain several observations of vertical land motion that cannot be explained by horizontal shortening or extension. Classic examples include the mid-Miocene uplift of southern Tibet and the Himalaya and the coeval onset of rapid deposition of the Siwalik series in the foreland basin. Canonical explanations involve removal of the mantle lithosphere (e.g., Harrison et al., 1992; Molnar et al., 1993) and elastic flexure of the lithosphere (e.g., Lyon-Caen \& Molnar, 1983). While each process is independently mechanically plausible, they are somewhat incompatible: If lithospheric unloading by removal of the lithospheric mantle in southern Tibet is invoked to explain the mid-Miocene uplift of southern Tibet and the High Himalaya, it implies that the vertical load exerted by the overriding lithosphere decreases. Removing the dense mantle lithosphere would counteract the overloading effect of the thickened crust, and the net result would arguably be to unload the overriding lithosphere. The flexural response of the subducting plate would adjust accordingly, and the unloaded overriding lithosphere would be incapable to increase the deflection but would perhaps decrease it. It follows that if delamination prevails in the upper plate, it therefore simultaneously rules out the lithospheric flexure hypothesis under an increased load at the plate boundary to explain the synchronous development of the foreland basin. In contrast, transient dynamic topography is a simple mechanism that provides a single explanation for these first-order observations. Here, we show that deposition and erosion of the Kailas Formation in the southern Lhasa terrane are further evidence of the same process.

Other explanations (e.g., Wang et al., 2015) invoke elasticity in the upper plate. Such a model would work if elasticity could prevail over long time scales (i.e., that of an orogen). We deem this hypothesis unlikely because the tectonically disrupted lithosphere and the high thermal regime suggest that viscous relaxation 


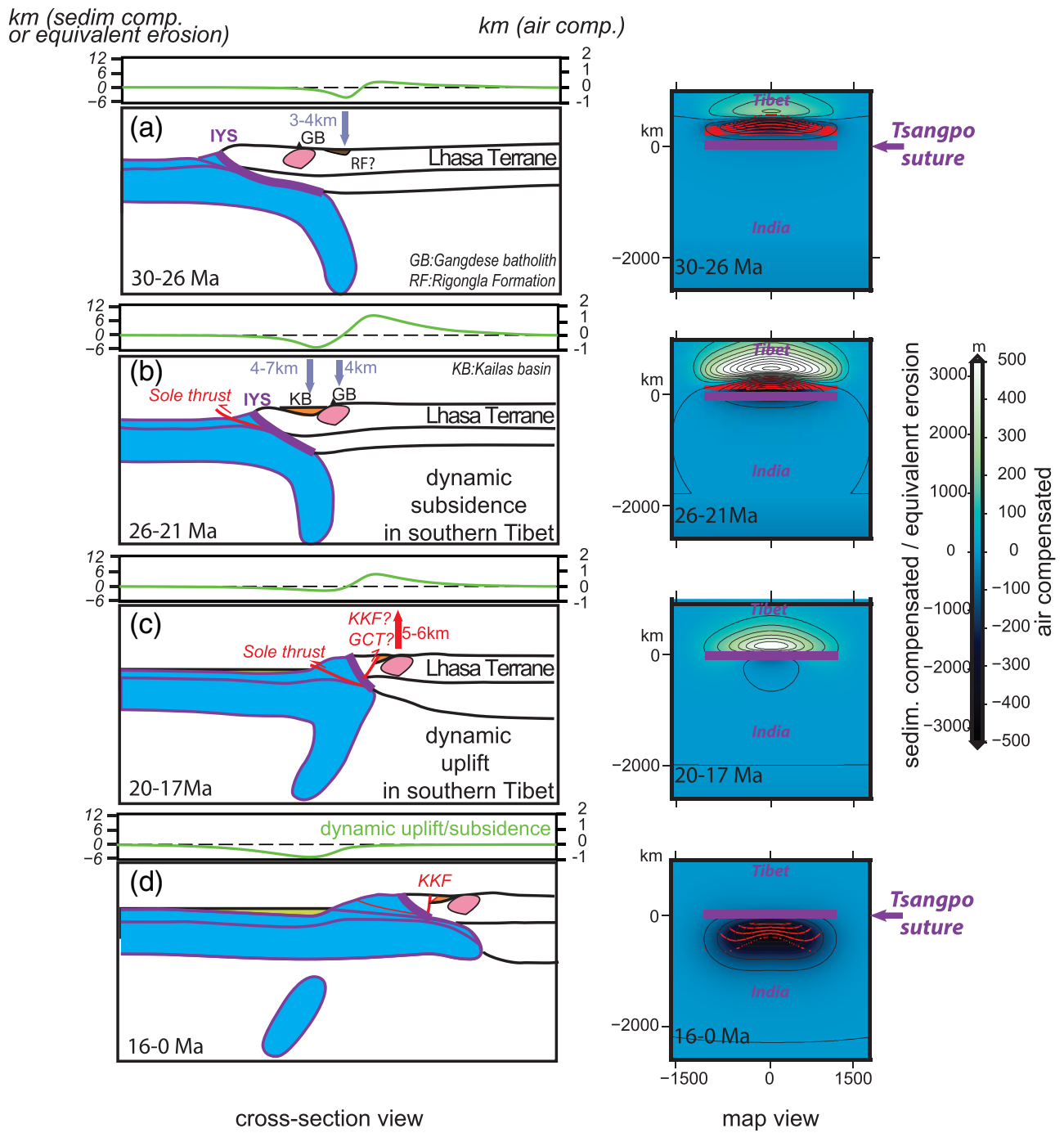

Figure 6. Simplified geodynamic evolution of Indian subduction, the Himalaya, and southern Tibet. Green curves above cross sections (left) and map views (right) of the modeled dynamic surface uplift and subsidence (differences in dynamic topography over the time frames) for an idealized Indian-Eurasian subduction zone, with dynamic surface uplift (air compensated), dynamic subsidence (sediment compensated), or equivalent erosion (assuming steady elevation). Slab geometries at each time are based on geophysical observations for present day, and geological arguments for past reconstructions in the past complemented by lessons from numerical and analog models (left). The black line is the zero isocontour, representing zero uplift/subsidence.

should quickly take over. Importantly, our model is conversely insensitive to the elasticity of the upper plate; the dynamic deflection only owes its origin to viscous fluxes in the mantle and its cessation to the release of the viscous traction underneath the surface. The subsequent rebound (Figure 6) is not due to any elastic rebound, but only to the restoration of isostatic equilibrium.

\subsection{Transient Subsidence Across the Lhasa Terrane}

The best fit line of thermal history shows the granites of the Gangdese batholith north of the Kailas basin after crystallization (50-40 Ma), began with a cooling to $\sim 200^{\circ} \mathrm{C}\left(60-350^{\circ} \mathrm{C}\right.$ with $95 \%$ confidence interval) during $\sim 40$ to $\sim 28$ Ma followed by a reheating phase between 28-26 and 21-20 Ma with temperature increasing to $320-420^{\circ} \mathrm{C}$, in the Kailas area (Figure $4 \mathrm{~b}$ ). This reheating is coeval with the heating of the Kailas Formation during its deposition between $\sim 26$ and $\sim 21 \mathrm{Ma}$ (Carrapa et al., 2014), suggesting that both the deeper sedimentary rocks of the basin and the underlying batholith were heated by the burial below thick sedimentation in a rapidly subsiding basin. Such burial is in agreement with our inversion of the thermal data 
showing that the batholith has been reheated to temperatures in excess of $320-420^{\circ} \mathrm{C}$ (Figure $4 \mathrm{~b}$ ). This implies that subsidence was not restricted to the present-day exposure of the Kailas basin but spanned a broader region including the current Gangdese batholith exposures, which also experienced burial. Isolated exposures of conglomerates atop the batholith (Figure 2) have been interpreted as local remnants of such a more extended Kailas Formation (Shen et al., 2019) (Figure 2).

Our dynamic models show that the southward migrating wave of dynamic topography implies a phase of dynamic subsidence. The initiation of deposition could have occurred north of the Gangdese magmatic arc south of the Lhasa terrane above the Indian slab, subducted since $\sim 35$ Ma after the Neo-Tethyan slab breakoff at 45 Ma (Guillot et al., 2003; Replumaz et al., 2014). The deposition of the Rigongla Formation at $\sim 31 \mathrm{Ma}$ along the northern margin of the Gangdese magmatic arc between Shiquanhe and Xigaze could correspond to this initial subsidence (Figure 6a). Dynamic topography modeling estimates subsidence amounting to $\sim 4 \mathrm{~km}$, compatible with the amount of sediment thickness between 3 and $4 \mathrm{~km}$ estimated for Rigongla Formation in Namling (Currie et al., 2016). Afterward, subsidence migrated southward as the northward drifting Indian plate moved above its own stationary slab, leading to an overturned geometry (Figure 6). During the Oligocene to Miocene (between 26 and $21 \mathrm{Ma}$ ), subsidence occurred in the Gangdese magmatic arc and Indus-Yarlung suture zone, yielding a maximum subsidence of $\sim 6 \mathrm{~km}$ between the magmatic arc and suture zone (Figure $6 \mathrm{~b}$ ). The current extent of the Kailas basin probably represents the location of the depocenter, which experienced $\sim 4 \mathrm{~km}$ of burial (Carrapa et al., 2014), and the magnitude of burial shallowed northward, with $\sim 4 \mathrm{~km}$ of burial in the Gangdese batholith according to our thermal modeling (Figure 6b). Moreover, according to the thermal model in this study, the $16-40^{\circ} \mathrm{C} / \mathrm{Myr}$ heating rate is compatible with a sediment accumulation rate of $0.5-1.3 \mathrm{~km} / \mathrm{Myr}$, which is consistent with the $4-7 \mathrm{~km}$ burial during 26-21 Ma at a deposition rate of 0.8-1.4 km/Myr (Carrapa et al., 2014).

Importantly, the dynamic deflection did not create the basin by itself: The southward increase in mantle traction during sedimentation only manifested as a southward tilt of the upper plate. For the deflection to be filled by water and sediments at an elevation of 1,500-2,900 m above sea level (Ai et al., 2019; DeCelles et al., 2011), the basin thus needed to be capable of storing sediments. This inference implies that the dynamic deflection could be recorded only in sedimentary basins in which the outlets of the drainage system were partly hindered by surrounding topographic highs (Figures 7a and 7b). Indeed, a paleoaltitude analysis has suggested that the Gangdese magmatic arc was slightly higher $(\sim 4,500 \mathrm{~m})$ than the area to the north $(<3,000 \mathrm{~m})$ (Ding et al., 2014), which provided ideal conditions for the deposition of the Rigongla Formation (Figure 6a). South of the Indus-Yarlung suture, even though the Himalaya range had not reached its highest elevations (Ai et al., 2019; DeCelles et al., 2011, 2018), the sediments deposited in the foreland basin in Nepal during the Oligocene (DeCelles et al., 2004; Najman et al., 2005) are indicative of some relief in the Himalaya, with elevation exceeded 3,600 $\mathrm{m}$ at the late Miocene (Chen et al., 2020). These ranges could have circumscribed an interior drainage system around the Kailas basin (Figure 7b). It follows that the dimensions of the Kailas basin were not exclusively set by the dynamic deflection itself but also by the elevations of the drainage outlets with respect to the depocenter. This difference in elevation dictated the thickness of the sedimentary layer that could be deposited at that time and, consequently, the extent of the Kailas basin in all directions. Geometrically, the basin thickens southward toward the Himalaya. This is attested by the fan shape of the formation, which has previously been interpreted as growth strata (e.g., Leary, DeCelles, et al., 2016). These rare conditions for sediment storage (instead of sediment export) explain why the extent of the sedimentary basin (possibly up to a maximum north-south width of $50 \mathrm{~km}$ at the time of deposition) is much narrower than the bulk dynamic deflection (several $100 \mathrm{~s}$ of $\mathrm{km}$ ) (Figures $7 \mathrm{~b}$ and $7 \mathrm{~d}$ ). Additionally, the dynamic deflection not only caused subsidence but also the subsequent uplift (see following section), which means that with the southward migration of the deflection, uplifted areas to the north would be exhumed and eroded, which provided sediments southward to the subsided Kailas basin. This implies the formation of proximal sedimentary facies in the subsiding basin, at least along its northern margin, is consistent with the alluvial fan lithofacies of the Kailas Formation in the early stage (DeCelles et al., 2011). Moreover, the ZFT peak age of the modern river sand from the central Lhasa terrane suggests that the volcanic rocks to the north of the Gangdese magmatic arc experienced exhumation at $\sim 27.3 \pm 1.3 \mathrm{Ma}$ (Figure 5). This timing is coincident with the initial reheating of the Gangdese batholith to the south according to the thermal modeling (Figure 4) and with the subsequent deposition in the Kailas basin. Volcanic gravel clasts, not granite, dominate the conglomerate clasts in the Kailas Formation, further indicating 


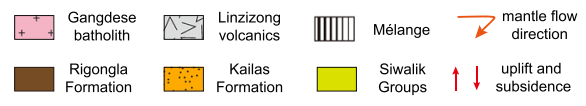

(a)

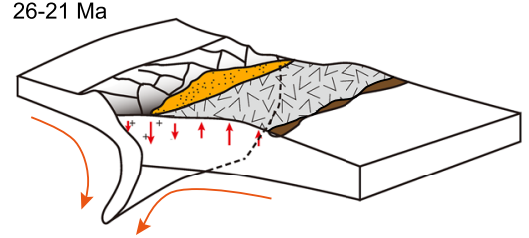

(c) $20-15 \mathrm{Ma}$

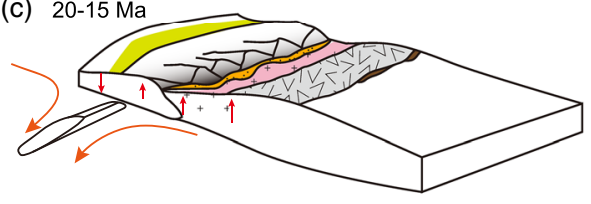

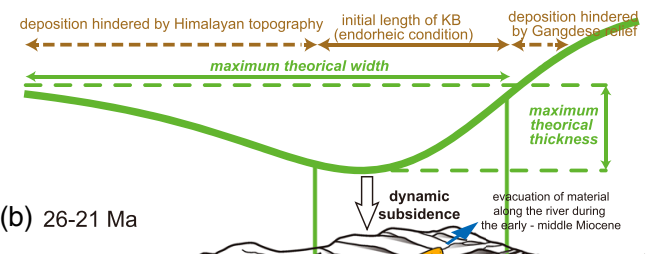

(b) $26-21 \mathrm{Ma}$

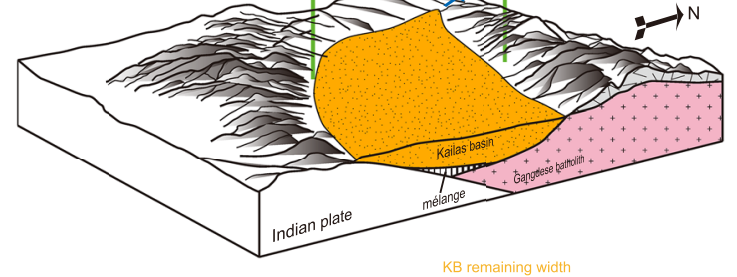

(d)

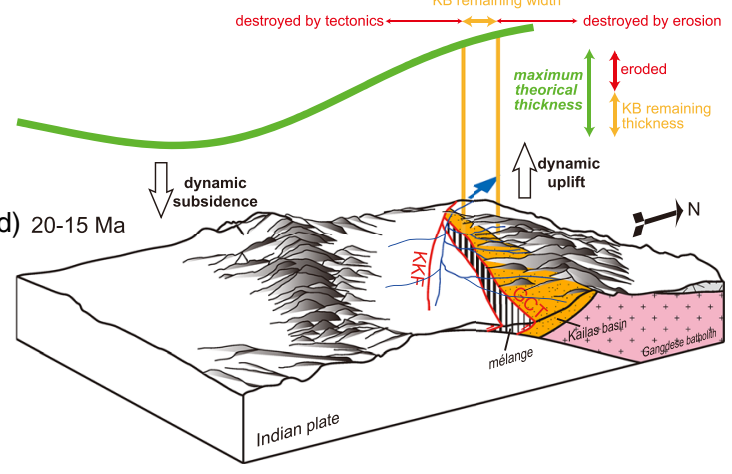

Figure 7. Schematic diagrams showing the dynamic deflection/uplift of southern Tibet. (a and b) Between 26 and 21 Ma, the southward migration of the dynamic deflection resulted in the uplift of the northern part of the Gangdese magmatic arc and subsidence of southernmost Tibet, forming the Kailas basin. (c and d) Beginning at approximately $20 \mathrm{Ma}$, surface uplift took place in southernmost Tibet, and subsidence migrated toward the front of the Himalaya, resulting in rapid exhumation of the Kailas Formation and Gangdese batholith. Panels d and e zoom in the topographic evolution around the Kailas basin during 26-21 and 20-15 Ma. The green curve on the top shows the dynamic subsidence (sediment compensated) as in the Figure 6.

that the main source of the sediments was the Linzizong volcanic rocks to the north, not the Gangdese batholith (DeCelles et al., 2011; Shen et al., 2019). Sedimentation ceased when the efficient river incision and evacuation of material from southern Tibet by the paleo-Yarlung River and Indus River occurred during the early to middle Miocene (Carrapa et al., 2017).

\subsection{Middle Miocene Uplift in Southern Tibet}

The period of subsidence in the sampled region was followed by a period of exhumation between 20 and $17 \mathrm{Ma}$. Considering a thermal gradient of $30^{\circ} \mathrm{C} / \mathrm{km}$ during this exhumation phase, the cooling is estimated to correspond to a minimum of $6.6 \mathrm{~km}$ of exhumation (6.6-13 km considering $95 \%$ confidence interval, according to the thermal model) (Figure 4). Similar magnitudes of exhumation are recorded during the same time interval across the Ladakh batholith (Kirstein et al., 2006), Kailas basin (Carrapa et al., 2014), Gyirong basin (Shen et al., 2016), Xigaze area (Dai et al., 2013; Ge et al., 2017, 2018) and eastern Tibet (Li, Kohn, et al., 2015; Tremblay et al., 2015) (Figures 1 and 8). The elevation of southern Tibet was still relatively low (1,500-2,900 m) during the time of deposition (26-21 Ma) of the Kailas Formation (Ai et al., 2019; DeCelles et al., 2011, 2018), while after the phase of exhumation (20-17 Ma), the Namling basin attained elevations of approximately 4,000 m (Spicer et al., 2003). Moreover, no major thrust faults or major deformation events are observed to be directly associated with the surface uplift of the Kailas basin, which lies in the footwall of the GCT, rests unconformably on the Gangdese batholith to the north (Figure 2), and has a well-preserved, seemingly isopachous stratigraphy (e.g., Yin et al., 1999). Besides, the rapid river incision along the Yarlung-Tsangpo River mainly occurred after $15 \mathrm{Ma}$ and was almost confined at the east of the Xigaze area (e.g., Dai et al., 2013; Li, Kohn, et al., 2015; Rohrmann et al., 2012), so that it also cannot account for the exhumation between 20 and $17 \mathrm{Ma}$ across the southern Tibet. 

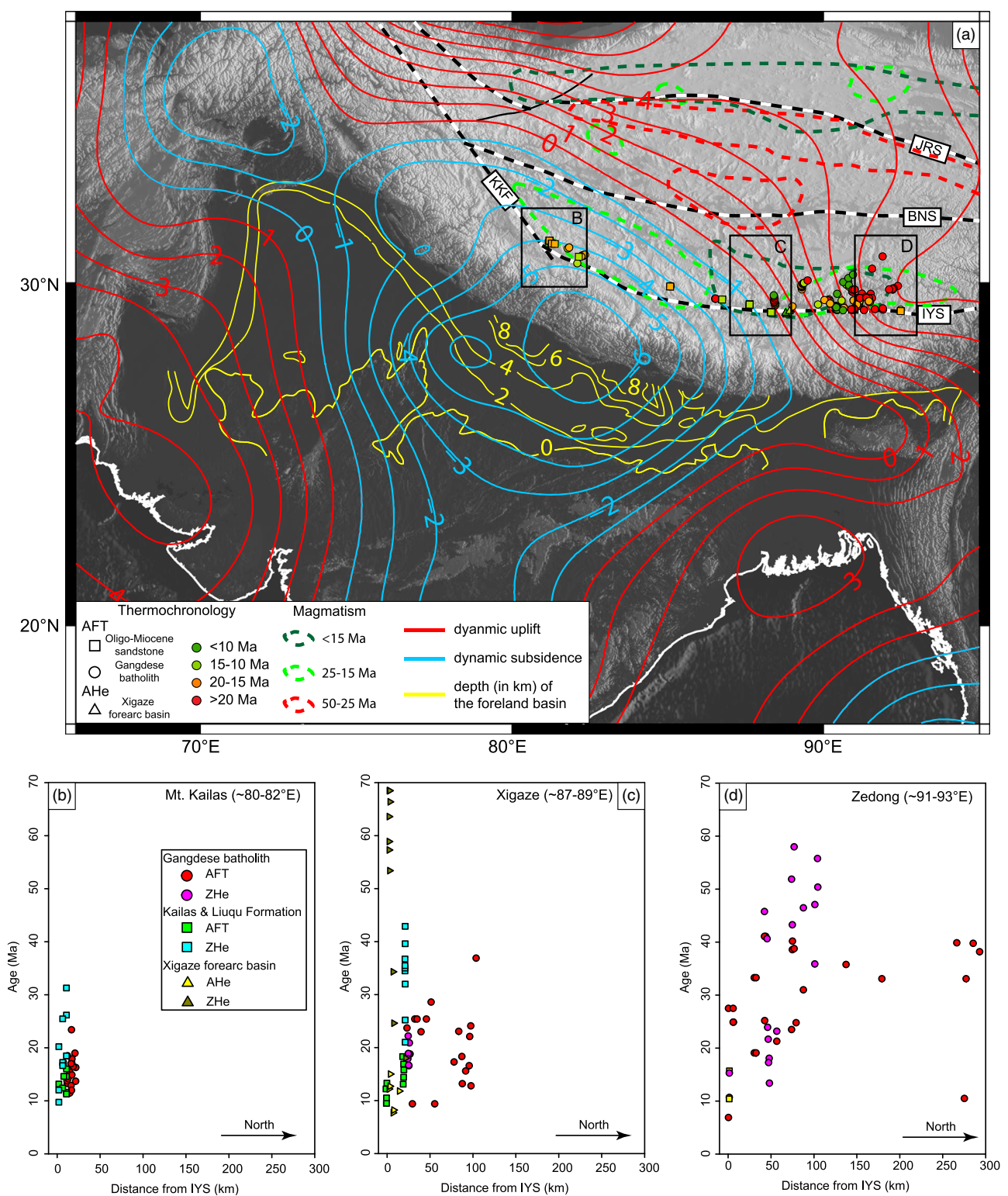

Figure 8. Compilation of the existing thermochronologic data in southern Tibet with the present-day dynamic deflection (Husson et al., 2014). (a) Distribution of the AFT and AHe data of the Kailas Formation, Gangdese batholith, and Xigaze basin with the model-predicted dynamic surface uplift (red) and subsidence (blue) at present day as well as the depth contours of the foreland basin (yellow) (Husson et al., 2014). The contour values (km) are for a sediment compensation of dynamic subsidence (blue) or erosion compensated dynamic surface uplift (red). In the absence of erosion or surface uplift, the magnitude should be divided by a factor of $~ 6$ (see Husson et al., 2014, for details). The age of magmatism contours by Goussin et al. (2020) are also illustrated. (b-d) AFT, AHe, and ZHe ages of the Kailas Formation, Gangdese batholith, and Xigaze basin against the distance from Indus-Yarlung suture zone in different locations. The data are summarized from Carrapa et al. (2014); Copeland et al. (1995); Dai et al. (2013); Ge et al. (2017, 2018); Li et al.

(2016, 2017); Li, Kohn, et al. (2015); Li, Tian, et al. (2015); Pan et al. (1993); Tremblay et al. (2015); Wang et al. (2007); Wang et al. (2015); Yang et al. (1999); Zhao et al. (2015); and this study.

In the absence of clear evidence for horizontal tectonics, our dynamic model provides an explanation. Once the downward deflection associated with the slab migrated to southern locations, the topography uplifted toward an isostatically compensated elevation (Figures $6 \mathrm{~b}$ and $7 \mathrm{a}$ ). The wave of surface uplift first occurred in the northern Gangdese magmatic arc, according to the young ZFT peak age of modern river sand from the central Lhasa terrane, showing exhumation at $27.3 \pm 1.3 \mathrm{Ma}$ (Figure 5), and then migrated southward. As the deflection migrated south of the Kailas basin, it first starved then eventually exhumed and eroded from 
20 Ma onward, while subsidence started in the Himalayan foreland basin (Figures $6 \mathrm{c}$ and 7c). Topographic subsidence may have bypassed the Himalaya itself or was perhaps diminished across the range. This could occur due to development of the orogenic wedge (i.e., the MCT active during the early Miocene, the MBT active during the late Miocene, and the MFT active during the Quaternary; e.g., Coutand et al., 2014; Kohn et al., 2001), such that tectonic shortening and concomitant crustal thickening (e.g., duplex systems) could have compensated for the otherwise predicted topographic deflection (Webb et al., 2017). Further exploration of the impacts of the relative southwards motion of the slab on the thrust tectonics, topography, and climate across the Himalayan orogenic wedge are presented in Webb et al. (2017).

The model-predicted dynamic surface uplift amounts to approximately $1 \mathrm{~km}$. This value is consistent with the estimated increase in elevation before and after rock cooling, according to fossil leaf evidence, which suggested a 1,500-2,900 m elevation for the Kailas basin at $23 \mathrm{Ma}$ (Ai et al., 2019) and a 4,638 $\pm 847 \mathrm{~m}$ elevation for southern Tibet at $15 \mathrm{Ma}$ (Spicer et al., 2003). The associated exhumation rates can be computed, to the first order, by assuming that isostatic equilibrium is restored when the elevation remains constant. This yields at maximum approximately $6 \mathrm{~km}$ of exhumation (Figure 6c), which is comparable to data from the Gangdese batholith. This exhumation was accompanied by intense surface erosion, reducing the present-day preserved thickness of the Kailas Formation (DeCelles et al., 2011, 2018) (Figure 7d). In practice, exhumation does not strictly result in a constant elevation, and some of the surface uplift is not compensated by erosion. The remainder has uplifted the Kailas basin in southern Tibet from its basin surface elevation during deposition (1,500-2,900 m), to its modern elevation of 4,500-6,700 m.

\subsection{Along-Strike Dynamic Deflection}

Along the Himalayan arc, the present-day dynamic deflection center (more than $6 \mathrm{~km}$ of sediment compensated deflection in the foreland) is located in the middle of the range, with no deflection below the eastern syntaxis, and a smaller amplitude to the west $(-2 \mathrm{~km})$, as shown by Husson et al. (2014) (Figure 8a). It is due to the geometry of the slab, whose center of mass is located below the middle of the Himalayan range along the arc-parallel direction (e.g., Replumaz et al., 2010, 2014). It has been similar since the Miocene time, with about $8 \mathrm{~km}$ of sediments deposited in the middle of the foreland basin along the arc-parallel direction, and less than $1 \mathrm{~km}$ close to the eastern and western syntaxes (Husson et al., 2014, and references therein).

Thermochronologic data reveal a similar longitudinal pattern for the Kailas formation, whose depocenter was located above the center of mass of the subducting slab, in the middle of the suture in the arc-parallel direction (Figure 8a). In the Mt. Kailas area, rapid exhumation occurred at circa 20-17 Ma for the Kailas Formation (Carrapa et al., 2014) with AFT ages mostly younger than 20 Ma (Figure 8b). To the east, in the Xigaze area, rapid exhumation occurred at circa 16-14 Ma for the Kailas Formation (Ge et al., 2018) and 16-10 Ma for the Liuqu Formation (Li, Tian, et al., 2015), with also AFT ages younger than $20 \mathrm{Ma}$ (Figure 8c). Between the Kailas Formation to the north and the Liuqu Formation to the south, the rocks from the Xigaze basin also experienced rapid exhumation at circa 16-15 Ma showing <20 Ma AFT (Figure 8c) (Li et al., 2017). In the Zedong area, thermal modeling also suggests rapid exhumation at 20-17 Ma for the Kailas Formation with AFT ages younger than $20 \mathrm{Ma}$ ( $\mathrm{Li}$, Kohn, et al., 2015) (Figure 8d). These thermochronologic data suggest all the late Oligocene to early Miocene deposits exposed south of the Gangdese magmatic arc have been experienced rapid exhumation around 20-15 Ma. However, the AFT ages of the Gangdese batholith are not fully confined to younger than $20 \mathrm{Ma}$, except in the Mt. Kailas area (this study) (Figure $8 \mathrm{~b}$ ). In the Xigaze area, granitic rocks located $\sim 50 \mathrm{~km}$ north of the suture zone have AFT cooling ages at around $25 \mathrm{Ma}$, and the $<20 \mathrm{Ma}$ ages are mostly limited close to the Kailas Formation (Figure 8c). The AFT ages of granitic rocks in the Zedong area are scatter from 60 to $15 \mathrm{Ma}$, and most of them are older than $20 \mathrm{Ma}$ (Figure 8d), indicating that the cooling ages of these granitic rocks were not reset by the deposition of the Kailas Formation probably due to shallow burial. This lack of young ages to the east of Tibet (Figure 8) and of the Himalaya (Webb et al., 2017), corresponding to a low amount of sedimentation in the Ganges basin (Figure 8a), suggests that the dynamic deflection center was in the Mt. Kailas area during the deposition of the Kailas formation (26-21 Ma) and in the Ganges basin (since $15 \mathrm{Ma}$ ) (Husson et al., 2014). The maximum of dynamic deflection result in deep subsidence and rapid uplift of both the Kailas Formation and the Gangdese batholith. To the east, the relatively old cooling ages of the Gangdese batholith and the young cooling ages of the Kailas Formation indicate shallow burial and reduced width of the Kailas Formation, implying a relatively small amplitude of deflection. 


\section{Conclusions}

Geodynamic models attempting to explain the India-Asia collision process must incorporate a mechanism that allows the southern fringe of the upper plate plateau to be topographically depressed during collision. Our new thermochronological data and modeling of samples from the Gangdese batholith in southwestern Tibet illustrate that not only the Kailas basin but also over a relatively large region in southern Tibet were topographically depressed. After being exposed at the surface, the Gangdese batholith experienced reheating during burial beneath the Kailas Formation between 28-26 and 21-20 Ma, followed by rapid cooling between 20 and $17 \mathrm{Ma}$. This thermal history is compatible with the results of dynamic topography modeling based on mantle dynamics. We show that the northward migration at the surface of the Indian continent above its own stationary slab induced a wave of dynamic topography, accompanied by a phase of subsidence in southern Tibet followed by a phase of uplift, as the dynamic deflection migrated southward to the Ganges basin. The computed estimate of the dynamic topography in the upper plate predicts approximately $\sim 4 \mathrm{~km}$ of dynamic subsidence, followed by $\sim 6 \mathrm{~km}$ of exhumation and $1 \mathrm{~km}$ of surface uplift in the southern Gangdese batholith, which are compatible with sedimentary and thermochronology observations.

The large-scale accumulation of sediments in the Kailas basin required conditions in which the sediments were not entirely transported out of the system by rivers at that time. The rivers draining the Gangdese batholith to the south did not cross the Himalaya range, which was rising during this period, thus providing the rare conditions necessary to block sediments in the interior of this elevated region. In fact, the very existence of the Kailas basin is itself surprising: Dynamic deflection alone is not sufficient; the sediments must have been able to settle instead of being washed out. The Kailas basin is thus perhaps the unique occurrence of a perched basin that owes its existence to dynamic topography, which temporarily offered the appropriate conditions for sediment storage, while most intermontane basins are likely explained by lateral variations of crustal tectonics.

\section{Data Availability Statement}

All the new thermochronological data are archived in Figshare repository (https://doi.org/10.6084/m9.figshare.11626053.v1).

\section{Acknowledgments}

This work has been supported by National Natural Science Foundation of China (41702208 and 41672195) and the China Geological Survey (Grant No. 1212011121261). Bowen Song, Junliang $\mathrm{Ji}$, Keke Ai, and Gaolei Jiang provided support during fieldwork. Melanie Balvay is acknowledged for help during the AFT and ZFT sample preparation. We also thank the suggestions by Djordje Grujic, Feng Cheng, Jonas Ruh, Giuditta Fellin, Barbara Carrapa, Devon A. Orme, Andrew Laskowski, and Peter G. DeCelles, which helped to significantly improve the manuscript.

\section{References}

Ai, K., Shi, G., Zhang, K., Ji, J., Song, B., Shen, T., \& Guo, S. (2019). The uppermost Oligocene Kailas flora from southern Tibetan Plateau and its implications for the uplift history of the southern Lhasa terrane. Palaeogeography Palaeoclimatology Palaeoecology, 515, $143-151$. https://doi.org/10.1016/j.palaeo.2018.04.017

Aitchison, J. C., Ali, J. R., \& Davis, A. M. (2007). When and where did India and Asia collide? Journal of Geophysical Research, 112 , B05423. https://doi.org/10.1029/2006JB004706

Bai, P., Xiong, X., Zeng, Y., Ma, D., Fu, H., Li, Y., et al. (2018). The discovery and significance of the sporopollen assemblages from the Oliogene Rigongla Formation in the Lunggar region Zhongba Xizang. Sedimentary Geology and Tethyan Geology, 38(3), 70-76.

Batchelor, G. (1967). An introduction to fluid mechanics. Cambridge: Cambridge University Press.

Burg, J.-P., Leyreloup, A., Girardeau, J., \& Chen, G.-M. (1987). Structure and metamorphism of a tectonically thickened continental crust: The Yalu Tsangpo suture zone (Tibet). Philosophical Transactions of the Royal Society of London. Series A, 321(1557), 67-86. https://doi. org/10.1098/rsta.1987.0005

Carrapa, B., Hassim, M. F. B., Kapp, P. A., DeCelles, P. G., \& Gehrels, G. (2017). Tectonic and erosional history of southern Tibet recorded by detrital chronological signatures along the Yarlung River drainage. Geological Society of America Bulletin, 129(5-6), 570-581. https:// doi.org/10.1130/B31587.1

Carrapa, B., Orme, D. A., DeCelles, P. G., Kapp, P., Cosca, M. A., \& Waldrip, R. (2014). Miocene burial and exhumation of the India-Asia collision zone in southern Tibet: Response to slab dynamics and erosion. Geology, 42(5), 443-446. https://doi.org/10.1130/g35350.1

Chapman, J. B., \& Kapp, P. (2017). Tibetan magmatism database. Geochemistry, Geophysics, Geosystems, 18, 4229-4234. https://doi.org/ 10.1002/2017GC007217

Chen, C., Bai, Y., Fang, X., Xu, Q., Zhang, T., Deng, T., et al. (2020). Lower-altitude of the Himalayas before the mid-Pliocene as constrained by hydrological and thermal conditions. Earth and Planetary Science Letters, 545, 116422. https://doi.org/10.1016/j.epsl.2020.116422

Cheng, J., \& Xu, G. (1986). Geologic map of the gaize region with report: Tibetan Bureau of Geology and Mineral Resources. Beijing: Geological Publishing House.

Chevalier, M. L., Ryerson, F. J., Tapponnier, P., Finkel, R. C., Van der Woerd, J., Li, H. B., \& Liu, Q. (2005). Slip-rate measurements on the Karakorum Fault may imply secular variations in fault motion. Science, 307(5708), 411-414. https://doi.org/10.1126/science.1105466

Chung, S. L., Chu, M. F., Zhang, Y. Q., Xie, Y. W., Lo, C. H., Lee, T. Y., et al. (2005). Tibetan tectonic evolution inferred from spatial and temporal variations in post-collisional magmatism. Earth-Science Reviews, 68(3-4), 173-196. https://doi.org/10.1016/j. earscirev.2004.05.001

Copeland, P., Harrison, T. M., Yun, P., Kidd, W. S. F., Roden, M., \& Zhang, Y. Q. (1995). Thermal evolution of the Gangdese batholith, southern Tibet-A history of episodic unroofing. Tectonics, 14(2), 223-236. https://doi.org/10.1029/94tc01676 
Coutand, I., Whipp, D. M., Grujic, D., Bernet, M., Fellin, M. G., Bookhagen, B., et al. (2014). Geometry and kinematics of the Main Himalayan Thrust and Neogene crustal exhumation in the Bhutanese Himalaya derived from inversion of multithermochronologic data. Journal of Geophysical Research: Solid Earth, 119, 1446-1481. https://doi.org/10.1002/2013JB010891

Currie, B. S., Polissar, P. J., Rowley, D. B., Ingalls, M., Li, S., Olack, G., \& Freeman, K. H. (2016). Multiproxy paleoaltimetry of the late Oligocene-Pliocene Oiyug basin, southern Tibet. American Journal of Science, 316(5), 401-436. https://doi.org/10.2475/05.2016.01

Dai, J., Wang, C., Hourigan, J., Li, Z., \& Zhuang, G. (2013). Exhumation history of the Gangdese batholith, southern Tibetan Plateau: Evidence from apatite and zircon (U-Th)/He thermochronology. The Journal of Geology, 121(2), 155-172. https://doi.org/10.1086/ 669250

DeCelles, P. G., Castaneda, I. S., Carrapa, B., Liu, J., Quade, J., Leary, R., \& Zhang, L. (2018). Oligocene-Miocene Great Lakes in the IndiaAsia Collision Zone. Basin Research, 30, 228-247. https://doi.org/10.1111/bre.12217

DeCelles, P. G., Gehrels, G. E., Najman, Y., Martin, A. J., Carter, A., \& Garzanti, E. (2004). Detrital geochronology and geochemistry of Cretaceous-Early Miocene strata of Nepal: Implications for timing and diachroneity of initial Himalayan orogenesis. Earth and Planetary Science Letters, 227(3-4), 313-330. https://doi.org/10.1016/j.epsl.2004.08.019

DeCelles, P. G., Kapp, P., Gehrels, G. E., \& Ding, L. (2014). Paleocene-Eocene foreland basin evolution in the Himalaya of southern Tibet and Nepal: Implications for the age of initial India-Asia collision. Tectonics, 33, 824-849. https://doi.org/10.1002/2014TC003522

DeCelles, P. G., Kapp, P., Quade, J., \& Gehrels, G. E. (2011). Oligocene-Miocene Kailas basin, southwestern Tibet: Record of postcollisional upper-plate extension in the Indus-Yarlung suture zone. Geological Society of America Bulletin, 123(7-8), 1337-1362. https://doi.org/ $10.1130 / \mathrm{b} 30258.1$

Dewey, J. F. (1988). Extensional collapse of orogens. Tectonics, 7(6), 1123-1139. https://doi.org/10.1029/TC007i006p01123

Ding, L., Xu, Q., Yue, Y., Wang, H., Cai, F., \& Li, S. (2014). The Andean-type Gangdese Mountains: Paleo elevation record from the Paleocene-Eocene Linzhou Basin. Earth and Planetary Science Letters, 392, 250-264. https://doi.org/10.1016/j.epsl.2014.01.045

Donelick, R. A., \& Miller, D. S. (1991). Enhanced TINT fission-track densities in low spontaneous track density apatites using cf-252derived fission fragment tracks-A model and experimental-observations. Nuclear Tracks and Radiation Measurements, 18(3), 301-307. https://doi.org/10.1016/1359-0189(91)90022-A

Donelick, R. A., O’Sullivan, P. B., \& Ketcham, R. A. (1999). Apatite fission-track analysis. Reviews in Mineralogy and Geochemistry, 58(1), 49-94. https://doi.org/10.2138/rmg.2005.58.3

Gallagher, K. (2012). Transdimensional inverse thermal history modeling for quantitative thermochronology. Journal of Geophysical Research, 117, B02408. https://doi.org/10.1029/2011jb008825

Ge, Y., Dai, J., Wang, C., Li, Y., Xu, G., \& Danisik, M. (2017). Cenozoic thermo-tectonic evolution of the Gangdese batholith constrained by low-temperature thermochronology. Gondwana Research, 41, 451-462. https://doi.org/10.1016/j.gr.2016.05.006

Ge, Y., Li, Y., Wang, X., Qian, X., Zhang, J., Zhou, A., \& Liu-Zeng, J. (2018). Oligocene-Miocene burial and exhumation of the southernmost Gangdese mountains from sedimentary and thermochronological evidence. Tectonophysics, 723, 68-80. https://doi.org/10.1016/j. tecto.2017.12.003

Gourbet, L., Maheo, G., Leloup, P. H., Paquette, J.-L., Sorrel, P., Henriquet, M., et al. (2017). Western Tibet relief evolution since the OligoMiocene. Gondwana Research, 41, 425-437. https://doi.org/10.1016/j.gr.2014.12.003

Goussin, F., Riel, N., Cordier, C., Guillot, S., Boulvais, P., Roperch, P., et al. (2020). Carbonated inheritance in the Eastern Tibetan lithospheric mantle: Petrological evidences and geodynamic implications. Geochemistry, Geophysics, Geosystems, 21, e2019GC008495. https:// doi.org/10.1029/2019gc008495

Guillaume, B., Martinod, J., Husson, L., Roddaz, M., \& Riquelme, R. (2009). Neogene uplift of central eastern Patagonia: Dynamic response to active spreading ridge subduction? Tectonics, 28, TC2009 https://doi.org/10.1029/2008tc002324

Guillot, S., Garzanti, E., Baratoux, D., Marquer, D., Maheo, G., \& de Sigoyer, J. (2003). Reconstructing the total shortening history of the NW Himalaya. Geochemistry, Geophysics, Geosystems, 4(7), 1064. https://doi.org/10.1029/2002GC000484

Gurnis, M., \& Zhong, S. (1991). Generation of long wavelength heterogeneity in the mantle by the dynamic interaction between plates and convection. Geophysical Research Letters, 18(4), 581-584. https://doi.org/10.1029/91GL00823

Harper, J. F. (1984). Mantle flow due to internal vertical forces. Physics of the Earth and Planetary Interiors, 36(3-4), 285-290. https://doi. org/10.1016/0031-9201(84)90052-9

Harrison, T. M., Copeland, P., Kidd, W. S. F., \& Yin, A. (1992). Raising Tibet. Science, 255(5052), 1663-1670. https://doi.org/10.1126/ science.255.5052.1663

Harrison, T. M., Watson, E. B., \& Aikman, A. B. (2007). Temperature spectra of zircon crystallization in plutonic rocks. Geology, 35(7), 635-638. https://doi.org/10.1130/G23505A.1

Harrison, T. M., Yin, A., Grove, M., Lovera, O. M., Ryerson, F. J., \& Zhou, X. H. (2000). The Zedong window: A record of superposed Tertiary convergence in southeastern Tibet. Journal of Geophysical Research, 105(B8), 19,211-19,230. https://doi.org/10.1029/ 2000JB900078

Heim, A., \& Gansser, A. (1939). Central Himalayan geological observations of the Swiss expedition. Zürich: Gebrüder Fretz.

Horton, B. K., Yin, A., Spurlin, M. S., Zhou, J., \& Wang, J. (2002). Paleocene-Eocene syncontractional sedimentation in narrow, lacustrine-dominated basins of east-central Tibet. Geological Society of America Bulletin, 114(7), 771-186. https://doi.org/10.1130/00167606(2002)114<0771:PESSIN>2.0.CO;2

Hu, X., Garzanti, E., Wang, J., Huang, W., An, W., \& Webb, A. (2016). The timing of India-Asia collision onset-Facts, theories, controversies. Earth-Science Reviews, 160, 264-299. https://doi.org/10.1016/j.earscirev.2016.07.014

Hurford, A. J., \& Green, P. F. (1982). A users' guide to fission track dating calibration. Earth and Planetary Science Letters, 59(2), 343-354. https://doi.org/10.1016/0012-821X(82)90136-4

Husson, L. (2006). Dynamic topography above retreating subduction zones. Geology, 34(9), 741-744. https://doi.org/10.1130/g22436.1

Husson, L., Bernet, M., Guillot, S., Huyghe, P., Mugnier, J.-L., Replumaz, A., et al. (2014). Dynamic ups and downs of the Himalaya. Geology, 42(10), 839-842. https://doi.org/10.1130/g36049.1

Husson, L., Guillaume, B., Funiciello, F., Faccenna, C., \& Royden, L. H. (2012). Unraveling topography around subduction zones from laboratory models. Tectonophysics, 526-529, 5-15. https://doi.org/10.1016/j.tecto.2011.09.001

Jackson, S. E., Pearson, N. J., Griffin, W. L., \& Belousova, E. A. (2004). The application of laser ablation-inductively coupled plasma-mass spectrometry to in situ U-Pb zircon geochronology. Chemical Geology, 211(1-2), 47-69. https://doi.org/10.1016/j.chemgeo.2004.06.017

Kapp, P., \& DeCelles, P. G. (2019). Mesozoic-Cenozoic geological evolution of the Himalayan-Tibetan orogen and working tectonic hypotheses. American Journal of Science, 319(3), 159-254. https://doi.org/10.2475/03.2019.01

Kapp, P., DeCelles, P. G., Leier, A. L., Fabijanic, J. M., He, S., Pullen, A., \& Gehrels, G. E. (2007). The Gangdese retroarc thrust belt revealed. Geological Society of America Today, 17(7), 4-9. https://doi.org/10.1130/GSAT01707A.1 
Kapp, P., Murphy, M. A., Yin, A., Harrison, T. M., Ding, L., \& Guo, J. H. (2003). Mesozoic and Cenozoic tectonic evolution of the Shiquanhe area of western Tibet. Tectonics, 22, 1029. https://doi.org/10.1029/2001TC001332

Ketcham, R. A., Carter, A., Donelick, R. A., Barbarand, J., \& Hurford, A. J. (2007). Improved measurement of fission-track annealing in apatite using c-axis projection. American Mineralogist, 92(5-6), 789-798. https://doi.org/10.2138/am.2007.2280

Ketcham, R. A., Donelick, R. A., \& Carlson, W. (1999). Variability of apatite fission-track annealing kinetics: III. Extrapolation to geological time scales. American Mineralogist, 84(9), 1235-1255. https://doi.org/10.2138/am-1999-0903

Kirstein, L. A., Sinclair, H., Stuart, F. M., \& Dobson, K. (2006). Rapid early Miocene exhumation of the Ladakh batholith, western Himalaya. Geology, 34(12), 1049-1052. https://doi.org/10.1130/g22857a.1

Kohn, M. J., Catlos, E. J., Ryerson, F. J., \& Harrison, T. M. (2001). Pressure-temperature-time path discontinuity in the Main Central thrust zone, central Nepal. Geology, 29(7), 571-574. https://doi.org/10.1130/0091-7613(2001)029<0571:pttpdi>2.0.co;2

Lacassin, R., Valli, F., Arnaud, N., Leloup, P. H., Paquette, J. L., Haibing, L., et al. (2004). Large-scale geometry, offset and kinematic evolution of the Karakorum fault, Tibet. Earth and Planetary Science Letters, 219(3-4), 255-269. https://doi.org/10.1016/s0012$821 x(04) 00006-8$

Laskowski, A. K., Kapp, P., \& Cai, F. (2018). Gangdese culmination model: Oligocene-Miocene duplexing along the India-Asia suture zone, Lazi region, southern Tibet. Geological Society of America Bulletin, 130(7-8), 1355-1376. https://doi.org/10.1130/b31834.1

Laskowski, A. K., Kapp, P., Ding, L., Campbell, C., \& Liu, X. (2017). Tectonic evolution of the Yarlung suture zone, Lopu Range region, southern Tibet. Tectonics, 36, 108-136. https://doi.org/10.1002/2016TC004334

Leary, R., DeCelles, P. G., Quade, J., Gehrels, G. E., \& Waanders, G. (2016). The Liuqu conglomerate, southern Tibet: Early Miocene basin development related to deformation within the Great Counter Thrust system. Lithosphere, 8(5), 427-450. https://doi.org/10.1130/L542.1

Leary, R., Orme, D. A., Laskowski, A. K., DeCelles, P. G., Kapp, P., Carrapa, B., \& Dettinger, M. (2016). Along-strike diachroneity in deposition of the Kailas Formation in central southern Tibet: Implications for Indian slab dynamics. Geosphere, 12(4), 1198-1223. https://doi.org/10.1130/ges01325.1

Li, G., Kohn, B., Sandiford, M., \& Xu, Z. (2017). India-Asia convergence: Insights from burial and exhumation of the Xigaze fore-arc basin, south Tibet. Journal of Geophysical Research: Solid Earth, 122, 3430-3449. https://doi.org/10.1002/2017JB014080

Li, G., Kohn, B., Sandiford, M., Xu, Z., Tian, Y., \& Seiler, C. (2016). Synorogenic morphotectonic evolution of the Gangdese batholith, South Tibet: Insights from low-temperature thermochronology. Geochemistry, Geophysics, Geosystems, 17, 101-112. https://doi.org/10.1002/ 2015GC006047

Li, G., Kohn, B., Sandiford, M., Xu, Z., \& Wei, L. (2015). Constraining the age of Liuqu conglomerate, southern Tibet: Implications for evolution of the India-Asia collision zone. Earth and Planetary Science Letters, 426, 259-266. https://doi.org/10.1016/j.epsl.2015.06.010

Li, G., Tian, Y., Kohn, B. P., Sandiford, M., Xu, Z., \& Cai, Z. (2015). Cenozoic low temperature cooling history of the Northern Tethyan Himalaya in Zedang SE Tibet and its implications. Tectonophysics, 643, 80-93. https://doi.org/10.1016/j.tecto.2014.12.014

Liu, Y., Hu, Z., Gao, S., Guenther, D., Xu, J., Gao, C., \& Chen, H. (2008). In situ analysis of major and trace elements of anhydrous minerals by LA-ICP-MS without applying an internal standard. Chemical Geology, 257(1-2), 34-43. https://doi.org/10.1016/j. chemgeo.2008.08.004

Liu, Y. S., Gao, S., Hu, Z., Gao, C., Zong, K., \& Wang, D. (2010). Continental and oceanic crust recycling-induced melt-peridotite interactions in the Trans-North China Orogen: U-Pb dating, Hf isotopes and trace elements in zircons of mantle xenoliths. Journal of Petrology, 51(1-2), 537-571. https://doi.org/10.1093/petrology/egp082

Ludwig, K. (2012). User's manual for Isoplot 3.75. A geological toolkit for Microsoft Excel, Berkeley Geochronology Center Special Publication No. 5. Berkeley: Berkeley Geochronology Center Special Publication.

Lyon-Caen, H., \& Molnar, P. (1983). Constraints on the structure of the Himalaya from an analysis of gravity-anomalies and a flexural model of the lithosphere. Journal of Geophysical Research, 88(NB10), 8171-8191. https://doi.org/10.1029/JB088iB10p08171

Mahéo, G., Blichert-Toft, J., Pin, C., Guillot, S., \& Pecher, A. (2009). Partial melting of mantle and crustal sources beneath South Karakorum, Pakistan: Implications for the Miocene geodynamic evolution of the IndiaAsia Convergence Zone. Journal of Petrology, 50(3), 427-449. https://doi.org/10.1093/petrology/egp006

Mahéo, G., Guillot, S., Blichert-Toft, J., Rolland, Y., \& Pecher, A. (2002). A slab breakoff model for the Neogene thermal evolution of South Karakorum and South Tibet. Earth and Planetary Science Letters, 195(1-2), 45-58. https://doi.org/10.1016/s0012-821x(01)00578-7

Miller, C., Schuster, R., Klotzli, U., Frank, W., \& Purtscheller, F. (1999). Post-collisional potassic and ultrapotassic magmatism in SW Tibet: Geochemical and $\mathrm{Sr}-\mathrm{Nd}-\mathrm{Pb}-\mathrm{O}$ isotopic constraints for mantle source characteristics and petrogenesis. Journal of Petrology, 40(9), 1399-1424. https://doi.org/10.1093/petrology/40.9.1399

Mo, X., Niu, Y., Dong, G., Zhao, Z., Hou, Z., Zhou, S., \& Ke, S. (2008). Contribution of syncollisional felsic magmatism to continental crust growth: A case study of the Paleogene Linzizong volcanic succession in southern Tibet. Chemical Geology, 250(1-4), 49-67. https://doi. org/10.1016/j.chemgeo.2008.02.003

Molnar, P., England, P., \& Martinod, J. (1993). Mantle dynamics, uplift of the Tibetan Plateau, and the Indian monsoon. Reviews of Geophysics, 31(4), 357-396. https://doi.org/10.1029/93RG02030

Morgan, W. J. (1965). Gravity anomalies and convection currents: 1 A sphere and cylinder sinking beneath the surface of a viscous fluid. Journal of Geophysical Research, 70(24), 6175-6187. https://doi.org/10.1029/jz070i024p06175

Murphy, M. A., \& Yin, A. (2003). Structural evolution and sequence of thrusting in the Tethyan fold-thrust belt and Indus-Yalu suture zone, southwest Tibet. Geological Society of America Bulletin, 115(1), 21-34. https://doi.org/10.1130/0016-7606(2003)115<0021:seasot>2.0.co;2

Najman, Y., Appel, E., Boudagher-Fadel, M., Bown, P., Carter, A., Garzanti, E., et al. (2010). Timing of India-Asia collision: Geological, biostratigraphic, and palaeomagnetic constraints. Journal of Geophysical Research, 115, B12416. https://doi.org/10.1029/2010JB007673

Najman, Y., Burley, S. D., Copley, A., Kelly, M. J., Pander, K., \& Mishra, P. (2018). The Late Eocene-Early Miocene unconformities of the NW Indian intraplate basins and Himalayan foreland: A record of tectonics or mantle dynamics? Tectonics, 37, 3970-3985. https://doi. org/10.1029/2018TC005286

Najman, Y., Carter, A., Oliver, G., \& Garzanti, E. (2005). Provenance of Eocene foreland basin sediments, Nepal: Constraints to the timing and diachroneity of early Himalayan orogenesis. Geology, 33(4), 309-312. https://doi.org/10.1130/G21161.1

Ning, Z., Zhang, L., Huntington, K. W., Wang, C., Dai, J., Han, Z., et al. (2019). The burial and exhumation history of the Liuqu conglomerate in the Yarlung Zangbo suture zone, southern Tibet: Insights from clumped isotope thermometry. Journal of Asian Earth Sciences, 174, 205-217. https://doi.org/10.1016/j.jseaes.2018.12.009

Pan, Y., Copeland, P., Roden, M. K., Kidd, W. S. F., \& Harrison, T. M. (1993). Thermal and unroofing history of the Lhasa area, southern Tibet-Evidence from apatite fission track thermochronology. Nuclear Tracks and Radiation Measurements, 21(4), 543-554. https://doi. org/10.1016/1359-0189(93)90195-F 
Pitard, P., Replumaz, A., Funiciello, F., Husson, L., \& Faccenna, C. (2018). Mantle kinematics driving collisional subduction: Insights from analogue modeling. Earth and Planetary Science Letters, 502, 96-103. https://doi.org/10.1016/j.epsl.2018.08.050

Pullen, A., Kapp, P., DeCelles, P. G., Gehrels, G. E., \& Ding, L. (2011). Cenozoic anatexis and exhumation of Tethyan Sequence rocks in the Xiao Curia Range, Southwest Tibet. Tectonophysics, 501(1-4), 28-40. https://doi.org/10.1016/j.tecto.2011.01.008

Ratschbacher, L., Frisch, W., Liu, G., \& Chen, C. C. (1994). Distributed deformation in southern and western Tibet during and after the India-Asian collision. Journal of Geophysical Research, 99(B10), 19,917-19,945. https://doi.org/10.1029/94JB0093

Replumaz, A., Capitanio, F. A., Guillot, S., Negredo, A. M., \& Villaseñor, A. (2014). The coupling of Indian subduction and Asian continental tectonics. Gondwana Research, 26(2), 608-626. https://doi.org/10.1016/j.gr.2014.04.003

Replumaz, A., Funiciello, F., Reitano, R., Faccenna, C., \& Balon, M. (2016). Asian collisional subduction: A key process driving formation of the Tibetan Plateau. Geology, 44911, 943-946. https://doi.org/10.1130/G38276.1

Replumaz, A., Negredo, A. M., Villasenor, A., \& Guillot, S. (2010). Indian continental subduction and slab break-off during Tertiary collision. Terra Nova, 22(4), 290-296. https://doi.org/10.1111/j.1365-3121.2010.00945.x

Replumaz, A., \& Tapponnier, P. (2003). Reconstruction of the deformed collision zone between India and Asia by backward motion of lithospheric blocks. Journal of Geophysical Research, 108(B6), 2285. https://doi.org/10.1029/2001JB000661

Rex, A. J., Searle, M. P., Tirrul, R., Crawford, M. B., Prior, D. J., Rex, D. C., \& Barnicoat, A. (1988). The geochemical and tectonic evolution of the Central Karakoram, North Pakistan. Philosophical Transactions of the Royal Society a-Mathematical Physical and Engineering Sciences, 326(1589), 229-255. https://doi.org/10.1098/rsta.1988.0086

Ricard, Y., Richards, M., Lithgowbertelloni, C., \& Lestunff, Y. (1993). A geodynamic model of mantle density heterogeneity. Journal of Geophysical Research, 98(B12), 21,895-21,909. https://doi.org/10.1029/93JB02216

Rohrmann, A., Kapp, P., Carrapa, B., Reiners, P. W., Guynn, J., Ding, L., \& Heizler, M. (2012). Thermochronologic evidence for plateau formation in central Tibet by 45 Ma. Geology, 40(2), 187-190. https://doi.org/10.1130/g32530.1

Sanchez, V. I., Murphy, M. A., Robinson, A. C., Lapen, T. J., \& Heizler, M. T. (2013). Tectonic evolution of the India-Asia suture zone since Middle Eocene time Lopukangri area, south-central Tibet. Journal of Asian Earth Sciences, 62, 205-220. https://doi.org/10.1016/j. jseaes.2012.09.004

Shen, T., Wang, G., Bernet, M., Replumaze, A., Ke, A., Song, B., et al. (2019). Long-term exhumation history of the Gangdese magmatic arc: Implications for the evolution of the Kailas Basin, western Tibet. Geological Journal, 1-12. https://doi.org/10.1002/gj.3539

Shen, T., Wang, G., Leloup, P. H., van der Beek, P., Bernet, M., Cao, K., et al. (2016). Controls on Cenozoic exhumation of the Tethyan Himalaya from fission-track thermochronology and detrital zircon U-Pb geochronology in the Gyirong basin area, southern Tibet. Tectonics, 35, 1713-1734. https://doi.org/10.1002/2016TC004149

Spicer, R. A., Harris, N. B. W., Widdowson, M., Herman, A. B., Guo, S. X., Valdes, P. J., et al. (2003). Constant elevation of southern Tibet over the past 15 million years. Nature, 421(6923), 622-624. https://doi.org/10.1038/nature01356

Spurlin, M. S., Yin, A., Horton, B. K., Zhou, J., \& Wang, J. (2005). Structural evolution of the Yushu-Nangqian region and its relationship to syncollisional igneous activity east-central Tibet. Geological Society of America Bulletin, 117(9), 1293-1317. https://doi.org/10.1130/ B25572.1

Tapponnier, P., Xu, Z., Roger, F., Meyer, B., Araund, N., Wittlinger, G., \& Yang, J. (2001). Oblique stepwise rise and growth of the Tibet Plateau. Science, 294(5547), 1671-1677. https://doi.org/10.1126/science.105978

Tremblay, M. M., Fox, M., Schmidt, J. L., Tripathy-Lang, A., Wielicki, M. M., Harrison, T. M., et al. (2015). Erosion in southern Tibet shut down at similar to 10 Ma due to enhanced rock uplift within the Himalaya. Proceedings of the National Academy of Sciences of the United States of America, 112(39), 12,030-12,035. https://doi.org/10.1073/pnas.1515652112

Valley, J. W., Cavosie, A. J., Fu, B., Peck, W. H., \& Wilde, S. A. (2006). Comment on "Heterogeneous Hadean hafnium: Evidence of continental crust at 4.4 to $4.5 \mathrm{Ga}$. Science, 312(1139a). https://doi.org/10.1126/science.1125301

Valli, F., Arnaud, N., Leloup, P. H., Sobel, E. R., Maheo, G., Lacassin, R., et al. (2007). Twenty million years of continuous deformation along the Karakorum fault, western Tibet: A thermochronological analysis. Tectonics, 26, TC4004. https://doi.org/10.1029/ 2005 TC001913

Van der Voo, R., Spakman, W., \& Bijwaard, H. (1999). Tethyan subducted slabs under India. Earth and Planetary Science Letters, 171(1), 7-20. https://doi.org/10.1016/s0012-821x(99)00131-4

Vermeesch, P. (2009). RadialPlotter: A Java application for fission track, luminescence and other radial plots. Radiation Measurements, 44(4), 409-410. https://doi.org/10.1016/j.radmeas.2009.05.003

Wang, E., Kamp, P. J. J., Xu, G., Hodges, K. V., Meng, K., Chen, L., et al. (2015). Flexural bending of southern Tibet in a retro foreland setting. Scientific Reports, 5(1), 12076. https://doi.org/10.1038/srep12076

Wang, G., Zhang, K., Xiang, S., Wang, A., \& Cao, K. (2014). Cenozoic geological map of the Tibetan Plateau and adjacent areas. Wuhan: Press of China University of Geosciences.

Wang, Y., Zhang, X., Sun, L., \& Wan, J. (2007). Cooling history and tectonic exhumation stages of the south-central Tibetan Plateau (China): Constrained by ${ }^{40} \mathrm{Ar} /{ }^{39} \mathrm{Ar}$ and apatite fission track thermochronology. Journal of Asian Earth Sciences, 29(2-3), 266-282. https://doi.org/10.1016/j.jseaes.2005.11.001

Webb, A. A. G., Guo, H., Clift, P. D., Husson, L., Mueller, T., Costantino, D., et al. (2017). The Himalaya in 3D: Slab dynamics controlled mountain building and monsoon intensification. Lithosphere, 9(4), L636-L651. https://doi.org/10.1130/1636.1

Williams, H. M., Turner, S. P., Pearce, J. A., Kelley, S. P., \& Harris, N. B. W. (2004). Nature of the source regions for post-collisional, potassic magmatism in southern and northern Tibet from geochemical variations and inverse trace element modelling. Journal of Petrology, 45(3), 555-607. https://doi.org/10.1093/petrology/egg094

Wu, Y. (1979). Tertiary of the Tibet. Beijing: Geological Publishing House.

Yamada, R., Murakami, M., \& Tagami, T. (2007). Statistical modelling of annealing kinetics of fission tracks in zircon; reassessment of laboratory experiments. Chemical Geology, 236(1-2), 75-91. https://doi.org/10.1016/j.chemgeo.2006.09.002

Yang, M., Nelson, F. E., Shiklomanov, N. I., Guo, D., \& Wan, G. (2010). Permafrost degradation and its environmental effects on the Tibetan Plateau: A review of recent research. Earth-Science Reviews, 103(1-2), 31-44. https://doi.org/10.1016/j.earscirev.2010.07.002

Yang, T. F., Wang, J. R., Lo, C. H., Chung, S. L., Tien, R. L., Xu, R., \& Deng, W. (1999). The thermal history of the Lhasa block, south Tibetan plateau based on FTD and Ar-Ar dating. Radiation Measurements, 31(1-6), 627-632. https://doi.org/10.1016/S13504487(99)00155-9

Yin, A. (2010). Cenozoic tectonic evolution of Asia: A preliminary synthesis. Tectonophysics, 488(1-4), 293-325. https://doi.org/10.1016/j. tecto.2009.06.002

Yin, A., \& Harrison, T. H. (2000). Geologic evolution of the Himalayan-Tibetan orogen. Annual Review of Earth and Planetary Sciences, 28(1), 211-280. https://doi.org/10.1146/annurev.earth.28.1.211 
Yin, A., Harrison, T. M., Murphy, M. A., Grove, M., Nie, S., Ryerson, F. J., et al. (1999). Tertiary deformation history of southeastern and southwestern Tibet during the Indo-Asian collision. Geological Society of America Bulletin, 111(11), 1644-1664. https://doi.org/10.1130/ 0016-7606(1999) $111<1644:$ tdhosa $>2.3 . c 0 ; 2$

Yin, A., Harrison, T. M., Ryerson, F. J., Wenji, C., Kidd, W. S. F., \& Copeland, P. (1994). Tertiary structural evolution of the Gangdese thrust system, southeastern Tibet. Journal of Geophysical Research, 99(B9), 18,175-18,201. https://doi.org/10.1029/94JB00504

Zhang, L., Ducea, M. N., Ding, L., Pullen, A., Kapp, P., \& Hoffman, D. (2014). Southern Tibetan Oligocene-Miocene adakites: A record of Indian slab tearing. Lithos, 210-211, 209-223. https://doi.org/10.1016/j.lithos.2014.09.029

Zhao, J., Qi, K., Li, G., Cao, M., Evans, N. J., McInnes, B. I. A., et al. (2015). The exhumation history of collision-related mineralizing systems in Tibet: Insights from thermal studies of the Sharang and Yaguila deposits, central Lhasa. Ore Geology Reviews, 65, 1043-1061. https://doi.org/10.1016/j.oregeorev.2014.09.026

Zhao, Z., Li, T., Luo, J., \& Lu, H. (2011). Stratigraphy of the Tibetan Plateau. Beijing: Science Press.

Zhu, D., Zhao, Z., Niu, Y., Mo, X., Chung, S., Hou, Z., et al. (2011). The Lhasa Terrane: Record of a microcontinent and its histories of drift and growth. Earth and Planetary Science Letters, 301(1-2), 241-255. https://doi.org/10.1016/j.epsl.2010.11.005

Zhu, Y., Fang, X., Gao, J., Yi, H., Wang, S., \& Zhang, W. (2006). Oligo-Mioence depositional facies of the Wuyu basin, southern Tibetan Plateau. Acta Sedimentologica Sinica, 24, 775-782. 